\title{
Restoration of the Western Himalaya: implications for metamorphic protoliths, thrust and normal faulting, and channel flow models
}

1. Dept. Earth Sciences, Oxford University, Parks Road, Oxford OX1 3PR, UK.E-mail: Mike.Searle@earth.ox.ac.uk

2. Shell Canada Energy, 400 - 4th Ave. SW, Calgary, Alberta, T2P 2H5, Canada.E-mail: Ben.Stephenson@shell.com

3. Imperial Oil Resources, ExxonMobil, 237 4th Ave. SW Calgary, Alberta, T2P 3M9, Canada. E-mail: James.d.walker@exxonmobil.com

4. CHP Consulting, London, EC2N 2HA, UK. E-mail: christian.walker@chp.co.uk

The Greater Himalayan Sequence (GHS) is composed of a sequence of Barrovian facies metamorphic rocks up to kyanite or sillimanite $+K$-feldspar grade, migmatites, layered stromatic migmatites and leucogranite sheets. These rocks were metamorphosed during the late Eocene to early Miocene, and are bounded below by a large-scale SW-vergent ductile shear zone-thrust fault (Main Central Thrust; MCT), and above by a NE-dipping low-angle normal sense shear zone and fault (Zanskar Shear Zone; ZSZ), part of the South Tibetan Detachment (STD) system. Restoration of the high-grade metamorphic rocks of the GHS reveals that protoliths are Proterozoic shales (Haimanta Group), Cambrian-Ordovician orthogneisses, Permian Panjal volcanics and Palaeozoic-Triassicl Jurassic sedimentary rocks, lateral equivalent rocks of the adjacent unmetamorphosed Tethyan zone. Structural outliers of low-grade or unmetamorphosed rocks (e.g., Chamba syncline) have been mapped overlying high-grade (usually sillimanite grade) rocks of the GHS. The low-grade klippen are underlain by lowangle north-directed ductile shear zones and normal faults, that are interpreted here as earlier equivalents of the ZSZ. These low-angle normal faults formed during continuous NE-SW compression, crustal thickening and southwestward extrusion of the GHS slab along the footwall. STD normal faults propagated structurally upward (northeast) with time, whereas MCT reverse faults along the base of the GHS propagated structurally downward (southwest) with time. Inverted metamorphic isograds along the base of the slab (MCT zone) can be linked on the map with right way-up isograds along the footwall of the ZSZ normal fault at the top of the slab, demonstrating that the recumbently folded isograd model is a viable geometrical representation of the metamorphic structure of the GHS. Post-metamorphic shearing along the ZSZ and MCT has condensed the isograds by a combination of pure shear and simple shear. These observations support the Channel Flow model of ductile extrusion of a mid-crustal layer of
Indian plate rocks during the Miocene, from beneath the passive roof stretching fault of the ZSZ.

\section{Introduction}

The structure of the Greater Himalaya (Figures 1,2,3) has recently been interpreted in terms of the south or southwestward ductile extrusion of a mid-crustal layer of partially molten rocks, a process known as "Channel Flow" (e.g., Nelson et al., 1996; Grujic et al., 1996, 2002; Beaumont et al., 2001; Searle et al., 2003, 2006; Searle and Szulc, 2005; Jessup et al., 2006). The idea that a ductile, partially molten layer of middle crust had been extruded southwest from beneath the Tethyan Himalaya and southern Tibet originated initially from field structural and metamorphic studies along the Himalaya. These studies recognized the spatial and temporal link between inverted metamorphic isograds along the base of the slab and right way-up isograds along the top (Searle and Rex, 1989). A low-angle, NNE-dipping ductile shear zone and thrust fault along the base (Main Central Thrust; MCT) and a lowangle, NNE-dipping shear zone and normal fault (Zanskar Shear Zone; ZSZ) along the top indicate that the middle crust has been extruded to the SSW by ductile flow. Both upper (ZSZ) and lower (MCT) boundaries of the extruding channel are ductile shear zones, up to $1.5-2 \mathrm{~km}$ wide, in which the isograds have been condensed by pure shear flattening strain as well as by SW-directed simple shear. Deep crustal seismic reflection and refraction profiles across southern Tibet from the INDEPTH project (Zhao et al., 1993; Nelson et al., 1996; Klemperer, 2006) showed that the middle crust beneath southernmost Tibet is composed of a partially molten layer with seismic "bright spots" interpreted as pockets of crustal melt magma forming today (Wei et al., 2001). The overall geometry of the Himalayan mid-crustal channel (Figure 3) is remarkably similar along the entire length of the Himalaya from Zanskar (Searle and Rex, 1989; Searle et al., 1992; 1999; Robyr et al., 2002; Steck, 2003), Lahoul (Wyss et al., 1999; Walker et al., 1999), through Garhwal- Kumaon (Metcalfe, 1993; Grasemann et al., 1999; Vannay and Grasemann, 2001), Nepal (Searle et al., 1997, 2003, 2006) and Sikkim (Searle and Szulc, 2005) to Bhutan (Grujic et al., 1996, 2002).

In the Himalaya, it has long been recognized that sedimentary rocks of the Tethyan zone along the northern margin of the Indian plate (rocks between the Indus suture zone to the north and the Greater Himalayan Sequence to the south) were shortened by folding and south- or SW-directed thrusting from the time of India- Asia collision (early Eocene) to the Oligocene (ca. 50-30 Ma; Searle, 1986; Searle et al., 1988, 1997; Corfield and Searle, 2000; Weismayr and Grasemann, 2002; Steck, 2003). At least 85 km of NE-SW shortening has been estimated across the Tethyan zone from restoration of 


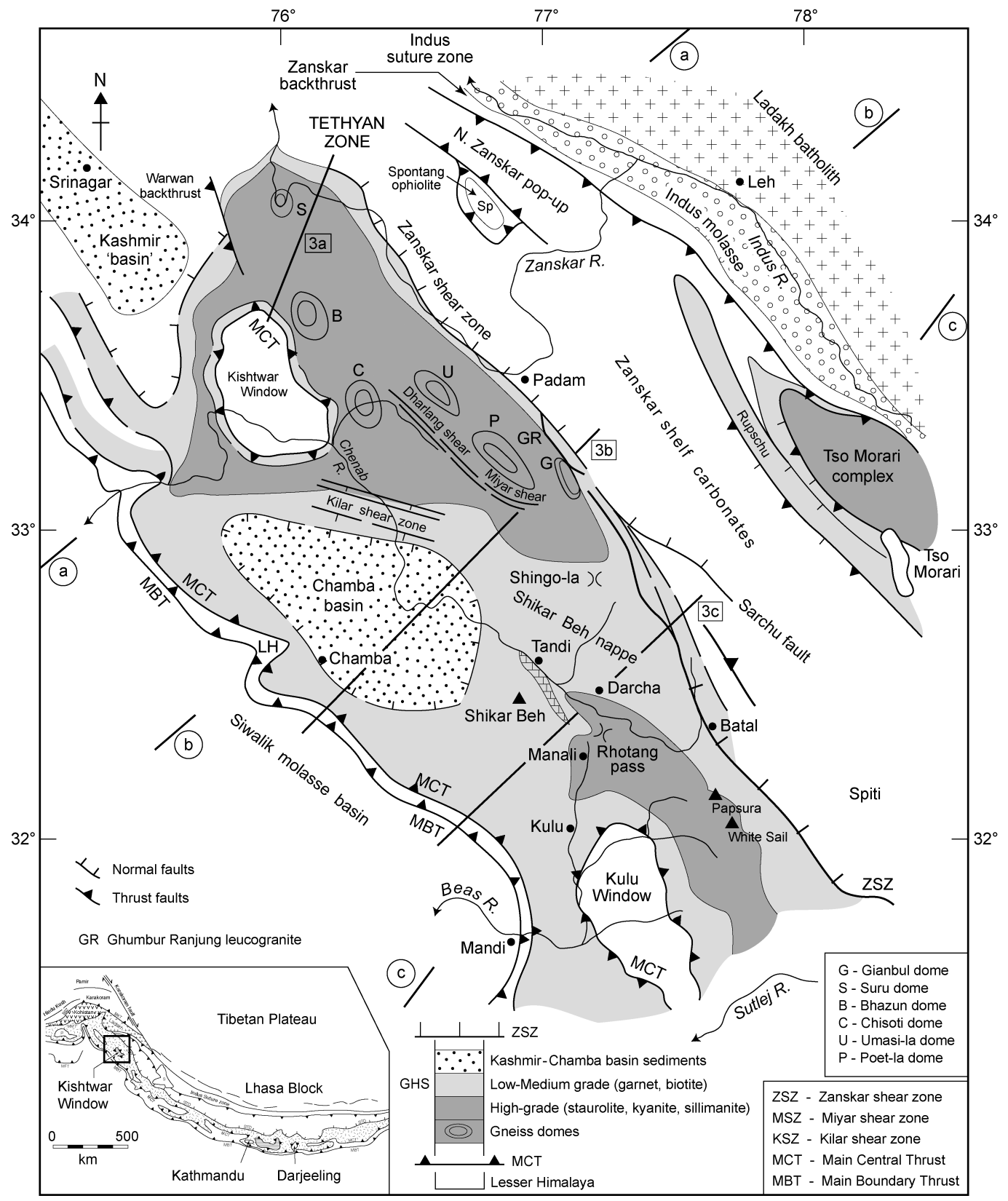

Figure 1 Metamorphic map of the Western Himalaya in the Zanskar, Kulu and Lahoul regions of the Indian Himalaya, showing major shear zones and faults and major structural units. Darker shading represents the staurolite, kyanite and sillimanite grade rocks, including in situ migmatites and leucogranites. Intermediate shading represents lower-grade greenschist facies rocks including garnet, biotite and chlorite grade schists within the GHS. Two major windows through the GHS into Lesser Himalayan rocks are the Kishtwar and Kulu Windows. The Kashmir and Chamba 'basins' occupy structural depressions. The Tso Morari dome in the far $N E$ represents an uplifted mid-crust extension of the GHS. This unit has been subducted to eclogite facies depths ( 27 kbar, 95-100 km depth) during the earliest phase of metamorphism and deformation.

balanced cross-sections (Corfield and Searle, 2000). MiocenePliocene NE-directed backthrusting has affected the entire northeastern margin of the Tethyan zone as well as the Indus suture zone (Searle, 1986; Corfield and Searle, 2000).

The southern margin of the Tethyan zone is the South Tibetan Detachment (STD), locally termed the Zanskar Shear Zone (ZSZ) in the western Himalaya, a low-angle, north-dipping normal fault which places unmetamorphosed Palaeozoic and Mesozoic sedimentary rocks above high-grade gneisses, migmatites and leucogranites of the GHS, and extends for some $2000 \mathrm{~km}$ along strike from Zanskar in the west to the Bhutan-SE Tibet region in the east (Burchfiel et al., 1992). The STD zone consists of a low-angle ductile shear zone containing down-to-north (or NE) kinematic indicators, consistent with southwestward extrusion of the footwall gneisses along a passive roof fault. Along the Everest profile, microstructure-based vorticity studies have shown that up to $40 \%$ pure shear occurs along the top of the GHS slab, as well as the dominant north-directed simple shear (Law et al. 2004; Jessup et al., 2006).

In the northwestern Himalaya, most of the highest mountains are composed of high-grade (staurolite, kyanite, sillimanite+muscovite, sillimanite+K-feldspar and migmatite) and low-grade (gar- net, biotite, chlorite) metamorphic rocks within the GHS (Figures 1,2). Two major tectonic windows through the GHS into Lesser Himalayan rocks (the Kishtwar and Kulu Windows) occur in the NW Himalaya. Two major piggy-back 'basins' - the Kashmir and Chamba synforms (or klippen) are also present overlying rocks of the GHS (Thakur, 1998). Figure 2 shows three sections across the GHS and Tso Morari dome, with the approximate geometries of the metamorphic isograds. Figure 3 shows three structural cross-sections across the GHS. The inverted isograds along the MCT zone at the base of the GHS have been mapped and join with the right wayup isograds along the ZSZ at the top of the GHS slab, in the far northwestern corner of the Zanskar GHS region, showing that the folded isograd model for the thermal structure of the GHS (Searle and Rex, 1989; Walker et al., 1999; Stephenson et al., 2000, 2001) is a correct geometrical model (Figure 4).

The precise location and nature of the MCT, the north-dipping high strain zone that places high-grade metamorphic rocks of the GHS over low-grade rocks of the Lesser Himalaya, has been the source of much controversy. Some authors place the MCT along the kyanite isograd (e.g., Colchen et al., 1986); others define two MCT's, a higher one in kyanite grade rocks and a lower one (MCT- 


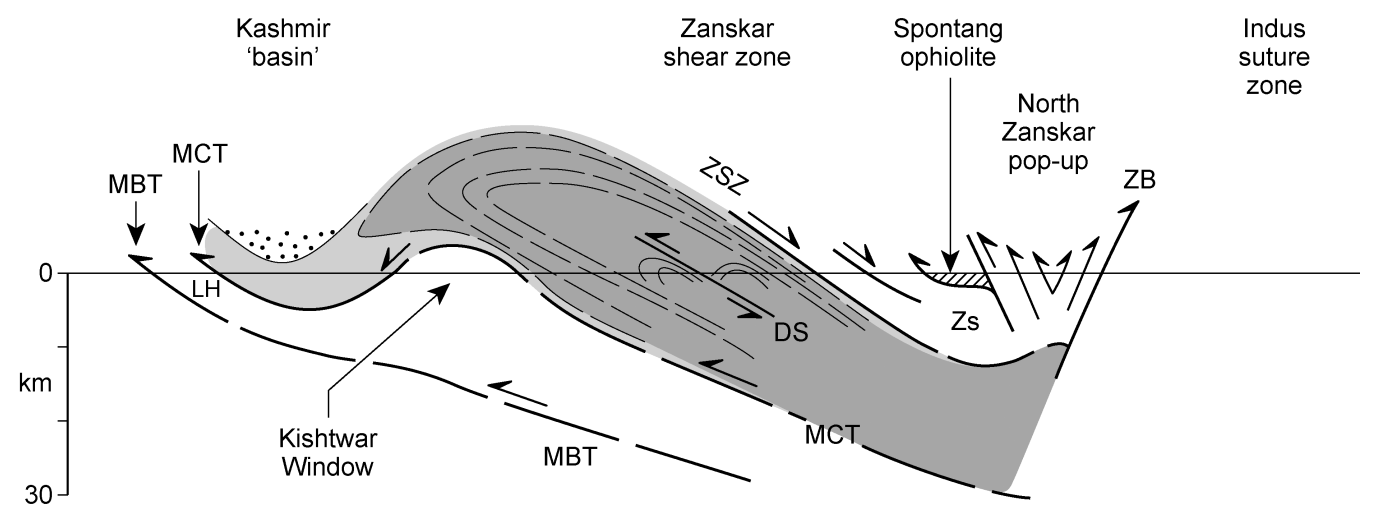

a)

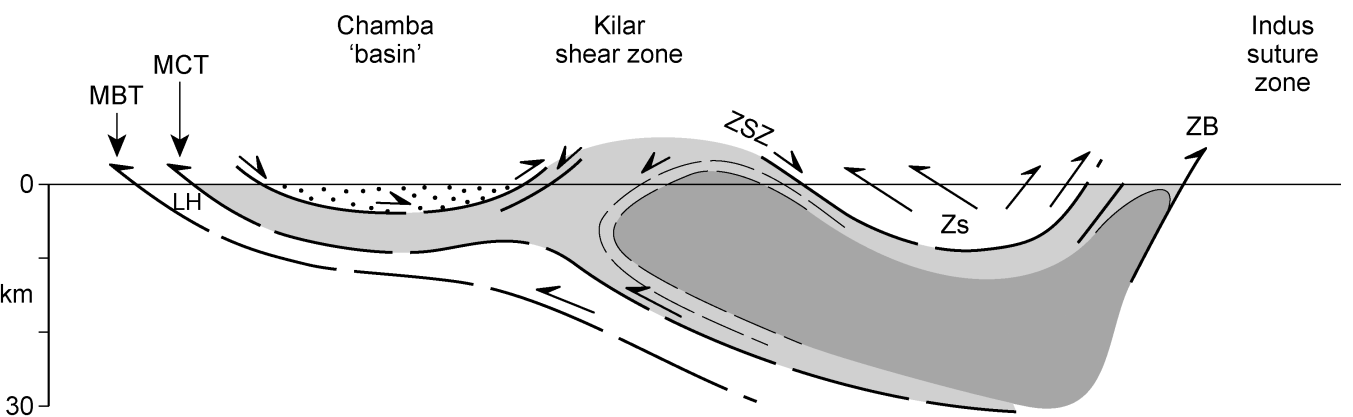

b)

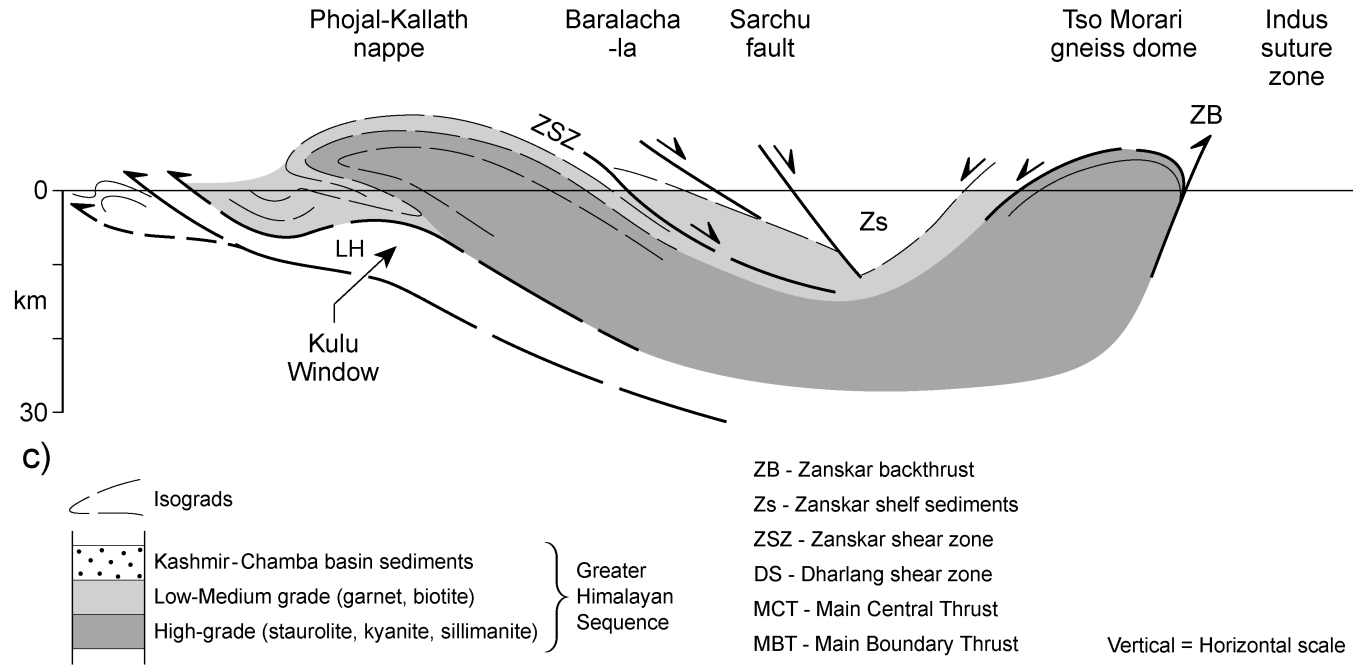

Figure 2 Three metamorphic cross-sections across the GHS and the Tso Morari dome in Zanskar and Kulu-Lahoul showing the structure of the GHS metamorphic zones and the disposition of metamorphic isograds; location of sections is shown on Figure 1.

1) along the base of the inverted metamorphic sequence (e.g., Arita, 1983; Catlos et al., 2003). Yet other authors place the MCT within the metamorphic slab, with sillimanite and kyanite grade rocks both below and above (e.g. Vannay and Grasemann, 1998, 2001; Weismayr and Grasemann, 2002). In all the MCT sections studied, both in the Kishtwar and Kulu Windows (Stephenson et al., 2000, 2001) and in Garhwal (Metcalfe, 1993), Nepal (Searle and Godin, 2003; Jessup et al., 2006), and Sikkim (Mohan et al., 1989; Searle and Szulc, 2005), the MCT zone is a ductile shear zone up to $2 \mathrm{~km}$ thick, coinciding precisely with the zone of inverted metamorphic isograds, which passes down to a brittle thrust fault along the base of the inverted metamorphic sequence (Figure 3).
This paper reviews the structural geometry of the GHS rocks, both in the Tso Morari (North Himalayan) dome and along the High Himalaya in the Zanskar-Chamba-Lahoul-Kulu Himalaya of northwest India. Several important ductile shear zones within the GHS, together with the structural relationships of the lowgrade klippen, are discussed. Mapping in the crucial region of eastern Kashmir and western Zanskar links the inverted metamorphic isograds along the MCT zone with the right way-up isograds along the ZSZ (Figure 4). This link is the key structural observation that supports channel flow extrusion of the GHS by at least $60-100 \mathrm{~km}$ to the south or southwest. This paper presents a restoration of the GHS across the Zanskar and Lahoul Himalaya showing the trajectories of the MCT and the ZSZ and the faults that underlie the 

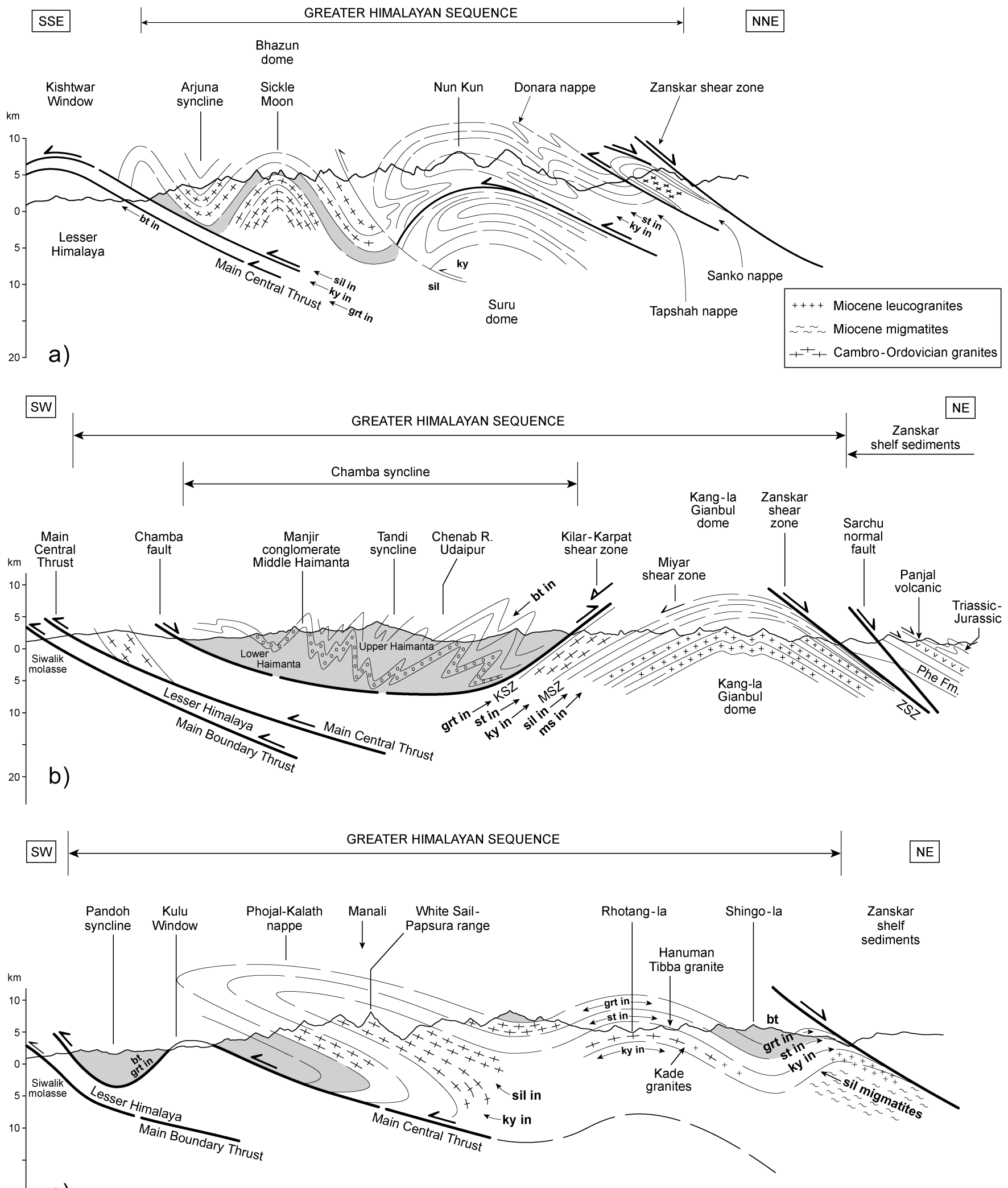

$20-$ C)

Figure 3 Three structural cross-sections across the Zanskar-Kishtwar GHS; locations shown on Figure 1.

(a) Kishtwar Window-Western Zanskar cross-section. SW-vergent recumbent nappes are folded around lower, later domes. Kyanite grade gneisses of the Suru nappes are thrust SW over sillimanite grade granite gneiss dome above the MCT zone of inverted metamorphic isograds.

(b) Eastern Zanskar-Chamba cross-section, showing high-level upright and NE-vergent folds in Chamba syncline above folded and domed GHS metamorphic rocks of the Kang-la-Gianbul dome.

(c) Kulu-Lahoul GHS cross-section, after Epard et al. (1995) and Walker et al. (1999), showing the SW-vergent Phojal-Kallath nappe above the MCT, folded around the Kulu Window. Note the shearing of right way-up isograds intro the ZSZ normal fault along the top of the GHS slab. 

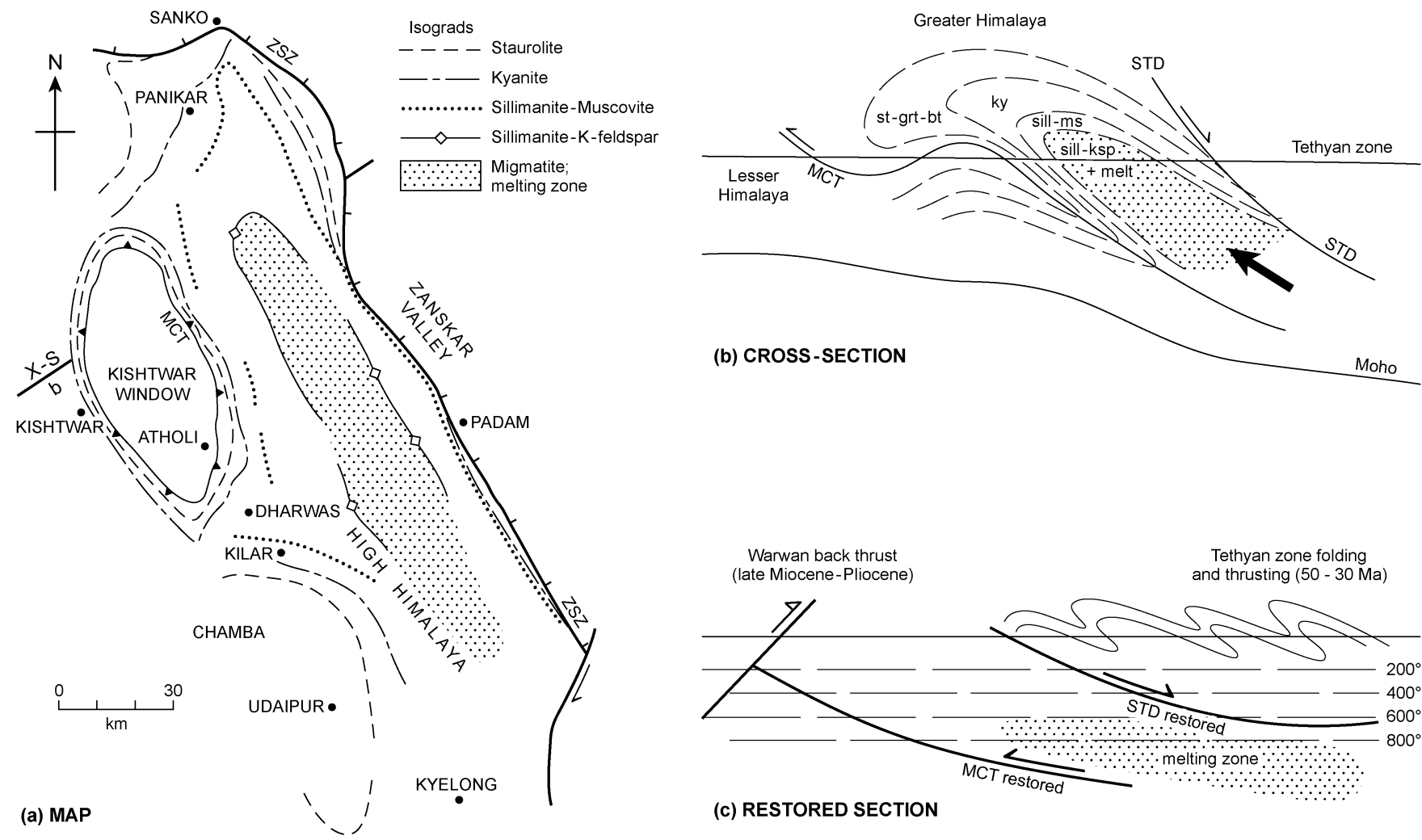

Figure 4 Map, cross-section and restored cross-section of the GHS in western Zanskar and eastern Kashmir, showing the relationships between the MCT, ZSZ and the Warwan backthrust.

Chamba and Kashmir synclines. The restoration shows that the Lesser, Greater and Tethyan Himalaya were a contiguous part of the Indian plate.

\section{Greater Himalayan Sequence (GHS) in Zanskar-Lahoul}

Mapping across the Kishtwar, Zanskar and Lahoul Himalaya reveals that the GHS forms a coherent tectonic unit that has undergone a polyphase metamorphic and deformation history (Kündig, 1989; Staubli, 1989; Searle et al., 1992, 1999; Dèzes et al., 1999; J. Walker et al., 1999; C. Walker et al., 2001; Stephenson et al., 2000, 2001; Robyr et al., 2002, 2006). The GHS includes a variety of Barrovian facies metamorphic rocks including pelites, calc-silicates, amphibolites, and K-feldspar augen gneisses. Cambrian-Ordovician orthogneisses occur across the entire GHS region. These rocks include granites such as the Deo Tibba-Hanuman Tibba-Jaspa granites, Kade granite and the Kaplas granite, with $\mathrm{Rb}-\mathrm{Sr}$ whole rock ages ranging from around $553 \pm 2$ Ma to $496 \pm 14$ Ma (Pognante et al., 1990; Frank et al., 1995; Miller et al., 2001) and high-grade orthogneisses such as the Rhotang gneiss.

Metamorphic isograds define a pattern of domes and depressions without major structural breaks between the chlorite-biotite and sillimanite zones (Figure 1). The higher structural levels of the GHS show a series of SW-verging and facing recumbent nappes that have been folded around lower, later domes (Figure 3). In the NunKun region of NW Zanskar, the Sankoo, Tapshah and Donara nappes have been folded around the Suru dome (Honegger, 1983; Searle et al., 1992; Walker et al., 2001). Metamorphic isograds cut across lithological and structural boundaries indicating that metamorphism was superimposed on a structurally thickened sequence. The originally right way-up isograds must have been folded by post- metamorphic deformation (Searle and Rex, 1989; Searle et al., 1992, 1999). Similar isograd geometries occur in SE Zanskar where the garnet, staurolite, kyanite and sillimanite-muscovite isograds have been folded around the deeper domal culminations around the Kang-la, Umasi-la and Gianbul domes (Figure 3; Walker et al., 1999; Robyr et al., 2002, 2006). Early NE-directed kinematic indicators show that at least some of the crustal thickening and prograde metamorphism was related to the early NE-directed Shikar Beh nappe emplacement (Steck et al., 1999; Robyr et al., 2002).

Much of the central part of the Zanskar range exposes migmatites with a vast network of leucogranitic sills and dykes which feed magma into the high-level leucogranites such as Ghumbur Ranjung. U-Pb dating of metamorphic monazites (Walker et al., 1999) and Sm-Nd dating of garnets in the Zanskar region (Vance and Harris, 1999) indicates that growth of metamorphic monazite and garnet was underway at 37-29 Ma. The deepest structural level exposed in the Zanskar GHS is represented by a series of gneiss domes, cored by Cambrian-Ordovician granites (Kündig, 1989). These granites have been metamorphosed to sillimanite+K-feldspar grade and affected by partial melting during the Tertiary Himalayan event. Migmatites mantle the domes and extend upwards into the overlying GHS pelites. Migmatite leucosomes containing tourmaline, garnet and muscovite have the same chemical and isotopic composition as the higher-level leucogranites (Searle and Fryer, 1986). U-Pb dating of high-U monazites from the melt pods shows that migmatization occurred at 20.6-19.5 Ma, similar ages as the high level leucogranites which range between 21-19.5 Ma (Noble and Searle, 1995; Walker et al., 1999; Dèzes et al., 1999).

Protoliths of the GHS metamorphic rocks are dominantly Proterozoic Haimanta Group sediments (Figure 5; Frank et al., 1973; Steck et al., 1993; Vannay and Steck, 1995; Walker et al., 1999) but also include Cambro-Ordovician granites and orthogneisses (Miller et al., 2001), Permian granites (Noble et al., 2001), Permian volcanic rocks (Panjal traps) and early Mesozoic sediments in 
northern Zanskar, partly equivalent to the un-metamorphosed rocks in the Tethyan zone (Figure 6; Searle, 1986; J. Walker et al., 1999; C. Walker et al., 2001). A widespread suite of peraluminous Cambrian- early Ordovician granites is prominent throughout the GHS. These anorogenic granites occasionally contain cordierite, andalusite, garnet and muscovite and have very high ${ }^{87} \mathrm{Sr} /{ }^{86} \mathrm{Sr}$ ratios ( $>0.7134)$ indicating a crustally derived source (Miller et al., 2001). Similar late Pan-African age granites occur in the core of the GHS gneiss domes and in the North Himalayan gneiss domes such as the Tso Morari dome (Stutz and Thöni, 1987; Girard and Bussy, 1999). U-Pb zircon dating of the Sankoo and Parkatchic garnet+biotite granites in Zanskar reveals an important set of Permian granites intruded at around $270 \mathrm{Ma}$ (Noble et al., 2001). All these granites within the GHS have been overprinted by staurolite, kyanite or sillimanite grade metamorphism during the Tertiary Himalayan event (Searle and Fryer, 1986; Searle et al., 1992; Walker et al., 2001), and only zircons retain evidence of their original crystallization age.

The GHS was metamorphosed to kyanite grade at 33-31 Ma as evidenced by Sm-Nd dating of garnets (Vance and Harris, 1999) and U-Pb dating of metamorphic monazites (Walker et al., 1999) from Zanskar. Temperatures remained high during active crustal shortening and thickening for at least a further 12 m.y until 22-20 $\mathrm{Ma}$, when peak sillimanite-grade metamorphism across the GHS slab was coincident with widespread migmatisation and crustal melting producing tourmaline, garnet and muscovite-bearing leucogranites (Noble and Searle, 1985; Searle et al., 1992; Walker et al., 1999; Dèzes et al., 1999; Robyr et al., 2006). Migmatite leucosomes within the GHS sourced the high level leucogranites such as the Ghumbur Ranjung leucogranite, via a network of sills and dykes (Searle and Rex, 1989; Searle et al., 1992, 1999; Walker et al., 1999; Dèzes et al., 1999). The evolution of the P-T conditions with time suggests an increase in temperature and decrease in pressure from early eclogite to later kyanite, then sillimanite grade metamorphism.

The upper structural levels of the GHS are cut by low-angle extensional faults beneath the Chamba syncline or 'basin' (Thakur, 1992, 1998) and along the contact with the overlying Tethyan sediments to the NE (Searle, 1986; Herren, 1987). Stratigraphy within the Chamba syncline is comparable to the protolith stratigraphy within the GHS (Figure 5) and at the lower structural levels of the Tethyan sequence (Figure 6). Middle-Late Eocene SW-directed thrusting and folding in the Tethyan zone resulted in shortening of the Indian plate upper crust above a detachment horizon along the base of the upper Haimanta-Phe Formation. As thrusting and folding propagated southwestward and down-structural section with time, the basal thrust fault was reactivated as a low-angle extensional normal fault (ZSZ). During the Oligocene-Miocene deformation and metamorphism in the GHS, this fault acted as a passive roof fault, with all the active deformation and metamorphism occurring in the footwall.

\section{Tso Morari granite-gneiss dome}

The Tso Morari complex is one of the North Himalayan gneiss domes, a series of domal culminations of metamorphic rocks along the leading margin of the Indian plate, usually regarded as the northward extension of the GHS (Figure 2). Lithologies are similar to the GHS with metapelites and metabasalts overlying deeper level orthogneisses. The orthogneisses are intruded by eclogitised basic dykes, that contain the mineral assemblage: garnet+omphacite+ quartz+glaucophane+phengite+paragonite+rutile. Metapelites are composed of garnet+jadeite+glaucophane+chloritoid+paragonite+ phengite \pm kyanite \pm staurolite \pm biotite and have been metamorphosed at P-T conditions of $550 \pm 5^{\circ} \mathrm{C}$ and $>20 \pm 3$ kbar (DeSigoyer et al., $2000,2004)$. Poorly constrained ages of $\sim 55$ Ma have been obtained using $\mathrm{Sm}-\mathrm{Nd}$, $\mathrm{Lu}-\mathrm{Hf}$ and $\mathrm{U}-\mathrm{Pb}$ dating methods but all have large error bars (DeSigoyer et al., 2000; Leech et al., 2005). Sachan et al. (2004) have determined the presence of coesite inclusions in omphacite, the high-pressure polymorph of $\mathrm{SiO}_{2}$, using Raman spectrometry, indicating pressures in excess of $27 \mathrm{kbar}$, related to depths of around $100 \mathrm{~km}$. Similar coesite eclogites from the northern margin of the India plate in the Kaghan valley, north Pakistan have P-T conditions of $27-29 \mathrm{kbar}$ and $690-750^{\circ} \mathrm{C}$ (O'Brien et al., 2001; Parrish et al., 2006). There is little doubt that the leading edge of the Indian plate was subducted to depths of nearly $100 \mathrm{~km}$ around the time of initial continental collision (50-47 Ma; Parrish et al., 2006). India-Asia continental collision is defined here as the timing of final marine sediments along the suture zone, at ca 50-49 Ma (Rowley, 1998; Zhu et al., 2005). This is a minimum age of collision, as the passive margin continental crust of India would have collided with the active margin of Asia prior to the final uplift above sea-level.

Metamorphism in the Tso Morari gneisses in the internal zone close to the Indus suture, occurred during the period 55-40 Ma (DeSigoyer et al., 2000; Schlup et al., 2003; Leech et al., 2005), whereas peak kyanite grade metamorphism in the High Himalaya (GHS) has been dated at 33-28 Ma using the Sm-Nd garnet method (Vance and Harris, 1999) and between 37-30 Ma using U-Pb monazite dating techniques (Walker et al., 1999). The Tso Morari eclogites and their enclosing gneisses were exhumed and decompressed rapidly from $\sim 100 \mathrm{~km}$ to around $40 \mathrm{~km}$ where they underwent blueschist facies re-equilibration at $\sim 11 \pm 2 \mathrm{kbar}$, and then were metamorphosed during the main Himalayan event under amphibolite facies conditions at $\sim 600^{\circ} \mathrm{C}$ and $7-10$ kbar (DeSigoyer et al., 2000). Exhumation of the UHP rocks was achieved between a large-scale extensional shear zone above (Ribil-Zildat fault) and a thrust fault below (Tso Morari shear zone).

\section{Chamba syncline-Haimanta Group}

The Neoproterozoic Haimanta Group (Greisbach, 1891) includes the thick pile of sedimentary rocks in the Chamba syncline (Figure 1), some $2-3 \mathrm{~km}$ thick that overlie the high-grade metamorphic rocks in the middle of the GHS. Frank et al. (1995) divided these rocks into Lower (Riphean), Middle (Vendian) and Upper (Vendian-Early Cambrian) Haimantas. The Lower Haimantas are comprised of a monotonous sequence of shales, siltstones and greywackes up to $5 \mathrm{~km}$ thick and are lateral equivalents of the Simla slates in the Lesser Himalaya. The Middle Haimanta Manjir conglomerate separates the Lower and Upper Haimantas (Frank et al., 1995). The Upper Haimantas in the Chamba syncline comprises a thick and monotonous sequence of sandstones and shales (Figure 5). The base of the Proterozoic sedimentary sequence is marked by a series of high strain shear zones, including the Kilar-Karpat shear zone and the structurally lower Miyar and Dharlang shear zones that place low-grade rocks above high-grade rocks (Figure 1).

The Upper Haimanta Group is the key stratigraphic horizon that can be correlated in the reconstruction across the entire Himalaya from the Lesser Himalaya below the MCT (Dogra-Simla slates) through the Greater Himalaya (Chamba syncline, and protoliths of sillimanite gneisses) to the base of the Tethyan Himalaya (Phe Formation) and the oldest protoliths exposed in the North Himalayan Tso Morari dome (Figure 7). Here, the Tso Morari graniteorthognesiss has a U-Pb zircon protolith age of $479 \pm 2 \mathrm{Ma}$ (Girard and Bussi, 1999). Zircons are the only mineral that has survived the Tertiary Himalayan metamorphic overprint in the GHS and North Himalayan domes. This trans-Himalayan stratigraphic correlation is evidence that the Greater and Lesser Himalaya were part of the Greater Indian plate (Searle, 1986; Myrow et al., 2003; Steck, 2003) and not separate terranes (c.f. DeCelles et al., 2000; Robinson et al., 2001). 


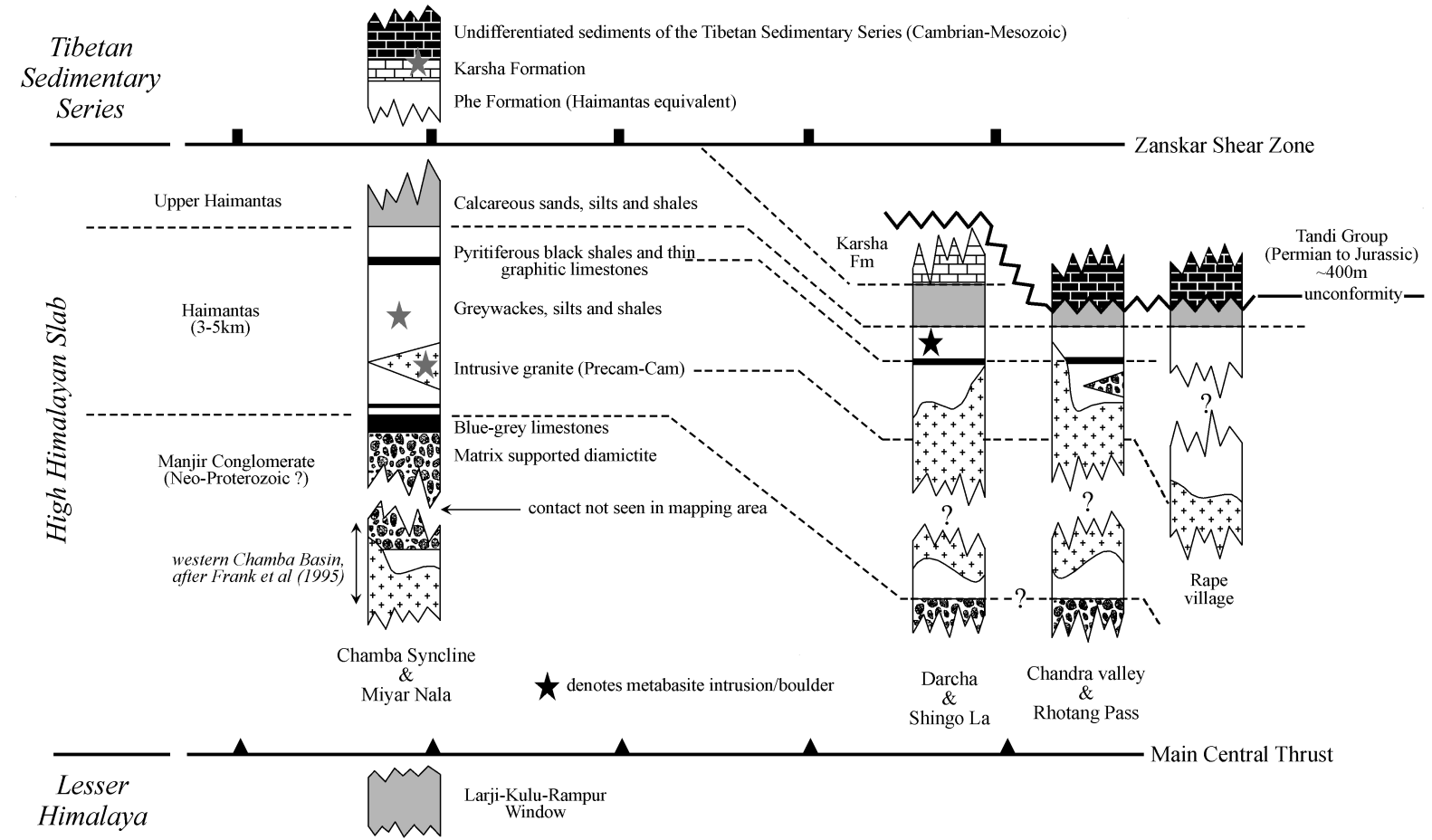

Figure 5 Stratigraphic correlation of lithologies within the GHS of Zanskar and Lahoul.

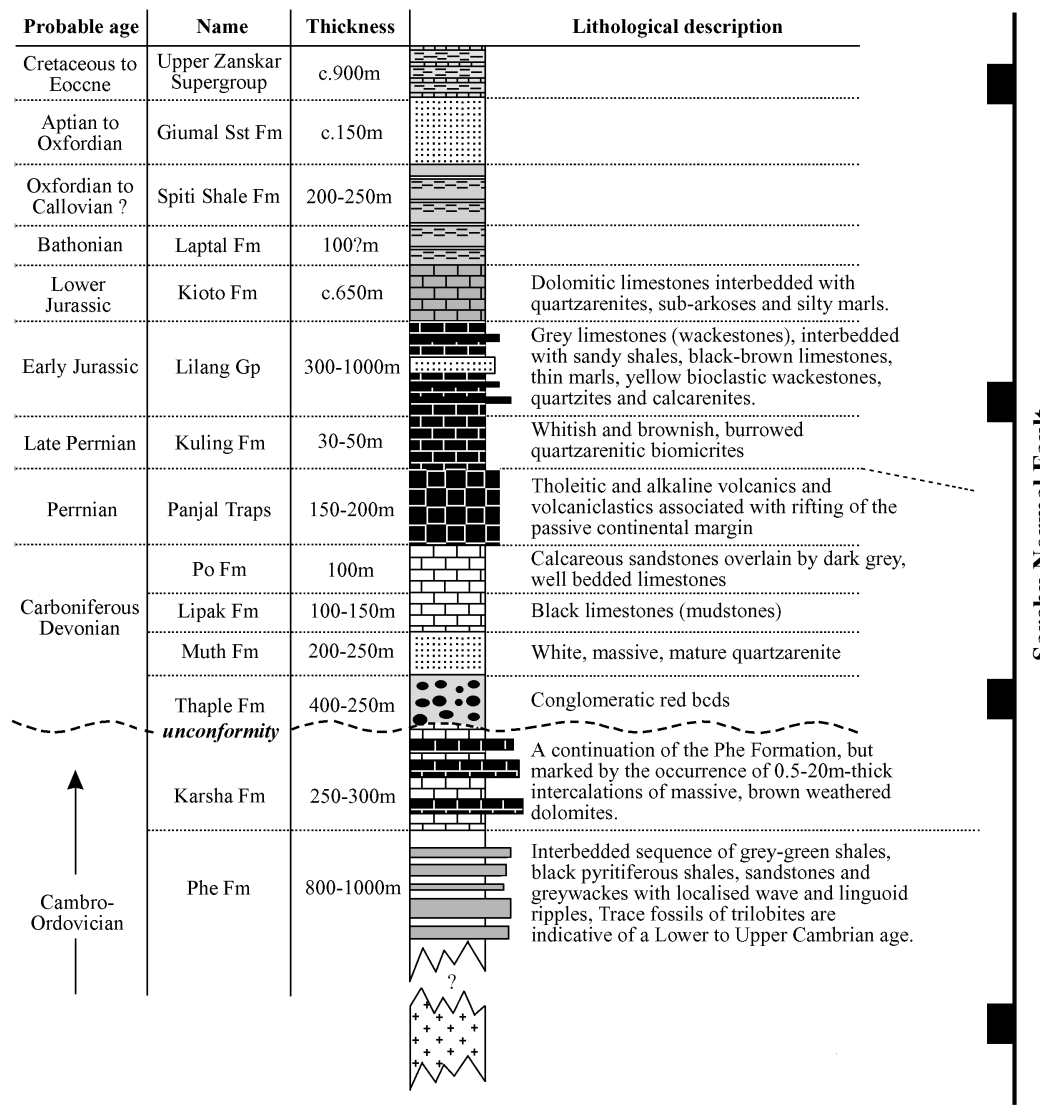

Tibetan Sedimentary Series of SE Zanskar

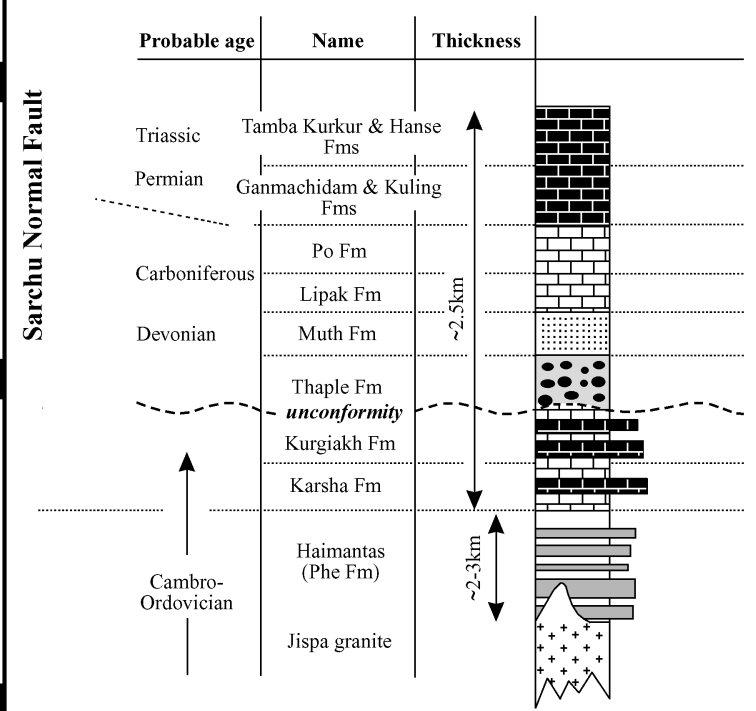

Upper part of High Himalayan Slab in NW Lahaul (north of Darcha)

Figure 6 Comparison of stratigraphic units across the Sarchu normal fault (SNF) in the upper part of the GHS in Lahoul. Stratigraphy of the Tibetan sedimentary series is summarized from Baud et al. (1984), Garzanti et al. (1987) and Gaetani and Garzanti (1991). Stratigraphy of the GHS is summarized from Spring and Crespo (1992) and Vannay and Steck (1995). 


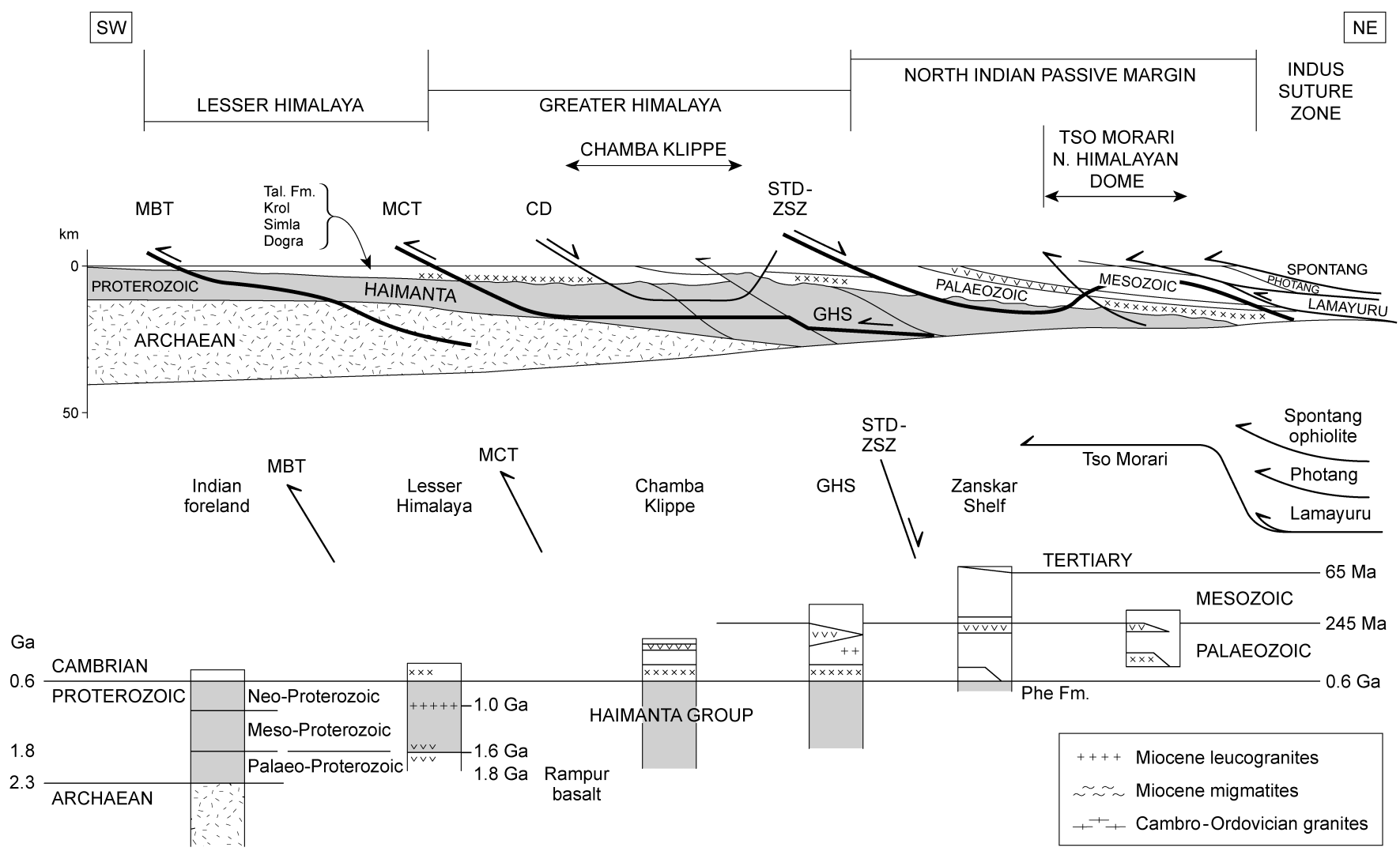

Figure 7 Restored section across the western Himalaya showing trajectories of the major shear zones and faults, following Searle (1986) and Steck (2003). Simplified stratigraphic columns below show the preserved rocks in the Lesser, Greater and Tethyan Himalayan zones. Note that the Neoproterozoic rocks of the upper Haimanta Group occur in all three structural zones.

\section{Zanskar Shear Zone (ZSZ)}

The ZSZ is part of the South Tibetan Detachment system of lowangle normal faults that bound the top of the GHS. Along the Zanskar valley the ZSZ is a $1-2 \mathrm{~km}$ wide zone of high ductile strain that is cut by a brittle normal fault along the top (Searle, 1986; Herren, 1987; Searle et al., 1988, 1992, 1999). Both ductile fabrics and the brittle normal fault dip between $20-35^{\circ} \mathrm{NE}$, and show ubiquitous down-to-NE shear sense kinematic indicators. Extensional fabrics within the ZSZ are superimposed onto earlier top-to-southwest thrust related fabrics showing that the ZSZ was a reactivated thrust fault. The extensional ductile shear zone has compressed the kyanite to biotite metamorphic isograds, which are right way-up and show extreme tectonic thinning. Peak metamorphic pressures between the kyanite and garnet isograds indicate approximately 5.8 kbar difference, indicating that roughly $18-20 \mathrm{~km}$ of pure shear flattening has occurred across the ZSZ (Walker et al., 1999; Robyr et al., 2002).

The Ghumbur Ranjung leucogranite is located immediately in the footwall of the ZSZ and is surrounded by kyanite grade gneisses above and sillimanite grade migmatites below (Figure 3 ). U-Pb monazite ages of the leucogranite are $22-21 \mathrm{Ma}$ and ${ }^{40} \mathrm{Ar} /{ }^{39} \mathrm{Ar}$ muscovite ages are only slightly younger, indicating a period of rapid cooling and exhumation immediately following crystallization and emplacement (Walker et al., 1999; Dèzes et al., 1999). Using P-T conditions of footwall metamorphic rocks, these authors determined horizontal slip distance of 60-40 km for the footwall metamorphic rocks and the Ghumbur Ranjung leucogranite beneath the ZSZ. The deepest exposed structural levels occur around Padam and the Zanskar valley. To the SE near Batal and the eastern Lahoul-Spiti region, higher structural levels show splays of normal faults cutting up into the Tethyan zone (Wyss et al., 1999). Late-stage normal faults, like the Sarchu normal fault, cut the ZSZ hanging-wall, and dip more steeply between $40-50^{\circ} \mathrm{NE}$. Some dextral shear is also apparent along the ZSZ in the Baralacha-la region.

It is clear from structural mapping and geochronology that the ZSZ was active at the same time as the MCT between $c a 22 \mathrm{Ma}$ and 16 Ma (Searle et al., 1992, 1999; Walker et al., 1999; Dèzes et al., 1999; Stephenson et al., 2000, 2001). It is also clear that the right way-up sillimanite to biotite isograds along the ZSZ link with the inverted isograds in the MCT zone and that the high grade gneisses, migmatites and leucogranites in between the two shear zones were extruded SW by at least $60 \mathrm{~km}$ (Searle and Rex, 1989). As the crustal shortening in the Tethyan zone propagated SW into the Greater Himalayan zone, the ZSZ locked and became a passive roof stretching fault. The folded and thrust Tethyan zone rocks above were static as the GHS rocks below were subducted, metamorphosed and exhumed along the hanging wall of the MCT zone. A 'passive roof duplex' was first defined by Banks and Warburton (1986) as a duplex whose roof sequence has a backthrust sense, and remains relatively stationary during 'piggy-back' foreland-directed thrust propagation within the underlying duplex. The 'passive roof fault' has a sense of shear opposite to the deforming footwall thrusts. Kinematic indicators along the ZSZ are down-to-NE whereas structurally lower in the GHS kinematic indicators show general shear (simple shear plus pure shear) with dominant SW-vergence, a sense of shear that continues southwestward all the way down to the MCT zone. 


\section{Shear zones within the GHS slab}

A number of ductile shear zones have been mapped within the GHS beneath the ZSZ and above the MCT (Figure 1). The deeper structural levels around the gneiss domes in Zanskar show ductile shear zones associated with exhumation of the domes. The shallower structural levels show ductile to brittle shear zones-faults that separate the low-grade Chamba syncline from the high-grade GHS.

\section{Kilar Shear zone (KSZ) - Chenab shear zone (CSZ)}

The KSZ (or CSZ) underlies the Chamba nappe (Figures 1, 2b, $3 b)$ and places weakly metamorphosed Proterozoic Haimanta Group sedimentary rocks over the high-grade gneisses of the GHS (Stephenson et al., 2000, 2001). There are three possible explanations for the kinematics of the KSZ. Firstly, the Chenab fault could be a down-to-SW normal fault rooting into the MCT (Thakur, 1992). Secondly, the CSZ could be interpreted as a SW-vergent thrust, folded by the Kishtwar Window dome, to become SW-dipping (Thakur, 1998). A third alternative interpretation is a NE-vergent low-angle normal fault placing low-grade Haimanta Group over high-grade GHS rocks, similar to the ZSZ to the NE, subsequently folded around the Kishtwar window dome. Stephenson et al. (2000, 2001) described top-to-ENE kinematic indicators, consistent with the third interpretation, that of a low-angle NE-vergent normal sense shear zone, similar to the ZSZ to the north.

\section{Miyar (Khanjar) shear zone (MSZ)}

The MSZ (Figures 1, 2a, 3b) was mapped by Pognante et al. (1990) as a thrust zone dipping $30-45^{\circ} \mathrm{SW}$ placing the 'cold' Kade unit northeastwards over the 'hot' sillimanite-grade GHS. Walker et al. (1999) mapped this contact as a $2 \mathrm{~km}$ wide zone of intense deformation affecting kyanite- and sillimanite-grade pelites and augen gneisses within the GHS. Robyr et al. $(2002,2006)$ also mapped it as an extensional (down to SW) shear zone within staurolite+kyanite grade gneisses. These authors termed this the Khanjar shear zone. Biotite, muscovite, kyanite and sillimanite define strong mineralstretching lineations that consistently plunge SW. Early fabrics are syn-metamorphic and related to crustal thickening and metamorphism. Extensional shear bands cross-cut, and are superimposed on, the earlier fabrics and show that the MSZ was a major detachment located above the sillimanite-grade Kang-la dome and beneath the low-grade Haimanta Group sediments of the Chamba basin (Figure 3b). Timing of ductile shear along the Miyar shear zone is constrained as between 26.6-22.5 Ma, the U-Pb age of early deformed and later undeformed leucogranites (Robyr et al., 2006). Metamorphic isograds were subsequently flattened by pure shear during extrusion of the GHS before final doming and folding. U-Pb ages show that deformation along the deeper MSZ occurred earlier than deformation along the higher ZSZ, which must have been after 22.2-19.8 Ma (Dèzes et al., 1999; Walker et al., 1999). This is good evidence that extensional shear zones propagated upwards with time along the top of the GHS slab.

\section{Dharlang shear zone (DSZ)}

The DSZ is located directly along strike with the MSZ (Figure 1) and was mapped by Stephenson et al. (2001). Extensional shear fabrics indicate a top-to-SSE shear sense, although the present orientation of the fabrics has resulted from late stage doming associated with deeper thrusting, probably along the MCT. The DSZ shows a wide zone of extensional fabrics and places sillimanite+muscovite gneisses without partial melting above sillimanite $+\mathrm{K}$-feldspar grade migmatites with abundant evidence of partial melting. The kinematics and metamorphism imply an extensional fault geometry to the DSZ and its extension in the Miyar nala (MSZ), but these shear zones are related more to exhumation of the high-grade core in the footwall, the partially melted slab that forms the highest mountains of the Zanskar range and includes the domal structures of Kang-la, Poet-la and Umasi-la (Figure 1). Between the Chamba syncline and the Tethyan zone a series of foliation-parallel shear zones place colder metamorphic units on top of hotter units and these shear zones are interpreted as similar to, but earlier, representations of the main Zanskar Shear Zone.

\section{Main Central Thrust zone}

The Main Central Thrust (MCT) is defined as the large-scale shear zone that places rocks of the GHS metamorphosed during the Tertiary Himalayan orogeny over Lesser Himalayan rocks that were largely unaffected by Tertiary metamorphism (e.g., Heim and Gansser 1939; Stephenson et al. 2001). After Heim and Gansser (1939) first described the MCT zone in the Munsiari area of Kumaon, the MCT has been re-designated and incorrectly mapped higher up-section, frequently in a position that follows the kyanite isograd, without supporting structural data. Bordet (1961) in the Makalu-Arun transect, eastern Nepal, Valdiya (1980) in Kumaon, north India, and Colchen et al. (1986) in the Annapurna region, west Nepal, all mapped the MCT in this higher location, and most subsequent workers have simply copied their mapping. This higher location for the MCT frequently corresponds to a lithological or stratigraphic-isotopic boundary; no strain data across this zone has been presented.

The MCT high-strain shear zone corresponds closely to the zone of inverted metamorphic isograds (sillimanite-kyanite down to garnet-biotite grade), indicating that shearing occurred after the isograds were formed during metamorphism. Within the MCT zone there are several zones of high strain and some authors have mapped two or more 'MCTs' (e.g., Arita 1983; Catlos et al., 2001, 2002). In almost every transect through the MCT zone, a ductile high-strain shear zone occurs around the kyanite isograd (sometimes referred to as MCT-2) and a brittle thrust is mapped along the garnet-biotite grade rocks (sometimes called MCT-1; Arita, 1983).

Around the Kishtwar Window, the MCT zone is a continuous high-strain shear zone between 1.5 and $3 \mathrm{~km}$ wide, precisely corresponding to the inverted metamorphic field gradient (Stephenson et al., 2000, 2001). At the higher levels kyanite grade gneisses metamorphosed at 9.5-10 kbar were exhumed from depths of 33-37 km, probably during, or shortly after peak metamorphism at 30-32 Ma (Vance and Harris, 1999; Walker et al., 1999). Shearing propagated structurally down-section from kyanite grade rocks into progressively lower grade staurolite, garnet and biotite grade rocks. The youngest thrusts cut through the lower grade rocks along the base of the MCT zone, and must have been active during or after $17 \mathrm{Ma}$, the ${ }^{39} \mathrm{Ar} /{ }^{40} \mathrm{Ar}$ cooling age of muscovites within the MCT zone (Stephenson et al., 2001). It is possible that even younger thrusts propagated down-section into the footwall of the 20-16 Ma proto-MCT. Vannay et al. (2004) mapped a 'Lesser Himalayan crystalline' thrust sheet beneath their higher MCT and above the Munsiari Thrust. This thrust sheet contains similar rocks to those above the higher thrust, also metamorphosed at similar P-T conditions $\left(600-700^{\circ} \mathrm{C}, 8 \mathrm{kbar}\right)$, but at younger time (youngest at 5.9 $\pm 0.2 \mathrm{Ma}$; Catlos et al., 2001 ). We interpret the 'Lesser (or 'Outer') Himalayan Crystalline' sheet as the same unit as the GHS; the younger monazite ages may simply reflect southward propagating metamorphism, cooling and thrusting within the GHS

The younger sillimanite grade metamorphism in the ZanskarKishtwar GHS peaked around 26-19.5 Ma, concomitantly with migmatisation and formation of leucosome melt pods and higher level leucogranite sills (Noble and Searle, 1995; Walker et al., 1999; Robyr et al., 2006). ${ }^{39} \mathrm{Ar} /{ }^{40} \mathrm{Ar}$ muscovite cooling ages across the entire GHS are younger than 17-16 Ma (Searle et al., 1992; Stephenson et al., 2001), indicating that the GHS was actively exhuming and therefore probably structurally high between 21-17 Ma. Since all the metamorphic isograds across the GHS have been folded around 
lower domes such as the Kishtwar and Kulu windows and around structural synclines, such as the Chamba syncline (Figure 1), this deformation and folding of isograds must have occurred after $17 \mathrm{Ma}$. The major GHS anticline axis (in the thermal structure represented by isograd geometry) plunges to the NW beneath the eastern Kashmir 'basin', and it is only in this area that the inverted isograds along the base of the GHS slab can be mapped and linked to the right wayup isograds along the top of the slab in the footwall of the ZSZ. The structural geometry (Figure 4) demonstrates that the large-scale SWvergent recumbent fold of isograds (Searle and Rex, 1989) is real, and that the entire GHS must have extruded towards the SW, beneath the passive roof fault of the ZSZ, during active culmination and uplift of the Greater Himalaya.

It has been suggested that the MCT represents a terrane boundary separating Greater and Lesser Himalayan rocks, based on different $\mathrm{Sr}$ and $\mathrm{Nd}$ isotopic values (DeCelles et al., 2000; Robinson et al., 2001, 2003), and different detrital zircon ages (Parrish and Hodges, 1996; DeCelles et al., 2000; Richards et al., 2005). Structural restoration of the entire GHS (Figure 7) shows that there was no plate boundary along the MCT as the rocks can be correlated across the entire Indian plate Himalaya from the Lesser Himalaya in the south to the North Himalayan domes outboard to the north (e.g., Steck, 2003; Searle et al., 2003, 2006).

\section{Warwan backthrust}

The western margin of the GHS in eastern Kashmir is a latestage NE-vergent backthrust termed the Warwan backthrust (Figure 1; Searle et al., 1992). In the Warwan valley Palaeozoic sedimentary rocks of the Kashmir basin have been thrust NE over kyanite grade gneisses of the GHS. The Warwan backthrust truncates the metamorphic isograds and all the GHS structures in the Donara and Tapshah nappes, and therefore must be younger than $14 \mathrm{Ma}$. It cannot be linked either temporally or spatially to the MCT (Yin, 2006), although it does cut across the present day topography at the line of the leading edge branch line between the MCT and the ZSZ. This branch line corresponds exactly to the leading edge of the GHS channel in the channel flow model (Figure 4).

\section{Restoration of the Zanskar GHS}

The GHS and the Chamba syncline in Zanskar, Kulu and Lahoul have been restored using structural, stratigraphic and isotopic data (Figure 7). Stratigraphic thicknesses show that the Mesozoic shelf sediments thicken towards the NE, towards the continental margin. The Permian Panjal volcanics are up to $2.5 \mathrm{~km}$ thick around the Kashmir valley and thin to only $\sim 100 \mathrm{~m}$ in Zanskar. The upper part of the GHS in the Suru valley comprises a series of calc silicates and marbles interpreted to be metamorphosed Triassic or Jurassic shelf carbonates, and garnet-bearing amphibolites interpreted as metamorphosed Panjal volcanics (Walker et al., 2001). The kyanite and sillimanite grade pelites are probably metamorphosed Haimanta Group shales, time equivalent rocks to the Phe Formation at the base of the Tethyan sequence.

The restored positions of the major shear zones and faults are also shown on the restored sections. The restoration confirms that stratigraphic units in the Vendian and Cambrian (Middle and Upper Haimantas) are continuous from the Lesser Himalaya across the Greater Himalaya to the Tethyan Himalaya. Also continuous across the Greater and Tethyan Himalayan zones are the widespread Cambrian-Ordovician granite-orthogneisses. The restorations show that the normal sense shear zones that underlie the Chamba and Kashmir synclines follow flats in the Haimanta Group shales for large horizontal distances. The geometry suggests that the earlier extensional faults are the Chamba and Kashmir faults, and are followed by the Zanskar shear zone fault and the Sarchu normal fault.
Lesser Himalayan granites beneath the MCT in the Kishtwar Window are Palaeoproterozoic with emplacement ages around 1.86-1.84 Ga and Nd depleted mantle model ages between 2.6 and 2.4, suggesting some contribution from Archean crust (Miller et al., 2001). In contrast, the structurally lowest $\mathrm{K}$-feldspar augen gneisses along the MCT zone in Nepal (e.g., Ulleri and Phaplu augen gneisses) have zircon ages around $1.2 \mathrm{Ga}$, whereas augen gneisses higher up within the GHS are dominantly Cambrian-Ordovician granites metamorphosed up to sillimanite grade during the Himalayan metamorphic event. This suggests that the MCT have had considerable out-of-sequence motion along it, placing younger GHS rocks onto older Lesser Himalayan rocks.

\section{Summary of structural-metamorphic chronology}

Earliest deformation fabrics in the GHS rocks could be Early Palaeozoic in age, formed during the Cambro-Ordovician orogenic event termed the Bhimphedian orogeny (Cawood et al., 2007). A major episode of deformation occurred along the northern margin of the Indian plate during the Late Cretaceous-Palaeocene, when suprasubduction ophiolites were obducted from the Tethyan Ocean onto the northern passive continental margin of India (Searle, 1986; Corfield et al. 2001). Post-collisional deformation was a continuum spanning the last 50 million years, and the major timings can be broadly summarized as follows:

D1-(55-45 Ma). The earliest phase of deformation and metamorphism ( $\sim 27 \mathrm{kbar} ; 550-600^{\circ} \mathrm{C}$; $\left.\sim 54-46 \mathrm{Ma}\right)$ occurred along the north Himalayan gneiss domes, in the Tso Morari region. Here, thinned continental crust was subducted to at least $94-100 \mathrm{~km}$ depth, forming coesite and micro-diamond-bearing eclogites (Figure 8a,b). It is not entirely clear whether these UHP eclogites were related to subduction of thinned continental crust beneath the obducting ophiolites, or whether they were related to the earliest phase of continental collision (DeSigoyer et al., 2000; Searle et al., 2001; Leech et al., 2005). The eclogites were exhumed rapidly back up the same subduction zone to the base of the crust at around 45-40 Ma (Schlup et al., 2003), where they underwent Barrovian facies Himalayan metamorphism, exhumation and cooling along with the North Himalaya GHS rocks during the subsequent deformation episodes.

D2-(50-35 Ma). The earliest deformation episode in the Greater Himalaya is represented by a phase of NE-facing folding associated with the NE-directed Shikar Beh nappe and Tandi syncline (Steck et al., 1999; Epard et al., 1995; Robyr et al., 2002). Fold axes are folded around lower, later domal structures beneath. NEfacing folding may be associated with NE-dipping deep subduction of the leading margin of the Indian plate as seen in the Tso Morari dome to the NE. Crustal thickening along the GHS resulted in kyanite grade metamorphism $\left(550-680^{\circ} \mathrm{C} ; 9.5-10.5 \mathrm{kbar} ; 37-30 \mathrm{Ma}\right)$ at depths of 35-45 km (Figure 8c).

D3-(35-26 Ma). This phase corresponds to the major episode of crustal folding, shortening and thickening that formed the SW-directed folds and thrusts of the Sankoo, Tapshah and Donara nappes in western Zanskar (Searle et al., 1988, 1992; Walker et al., 2001) and the large-scale Phojal-Kallath nappe in the Kulu- Lahoul region (Walker et al., 1999; Steck, 2003). At least one phase of deformation occurred pre-peak kyanite metamorphism, as shown by isograds cutting across earlier fold structures, and another major phase followed peak kyanite and sillimanite metamorphism, as shown by the folding of metamorphic isograds. Prograde kyanite metamorphism peaked around 35-30 Ma (Vance and Harris, 1999; Walker et al., 1999).

D4-(26-18 Ma). This phase corresponds to the timing of peak sillimanite grade metamorphism $\left(650-770^{\circ} \mathrm{C} ; 4.5-7\right.$ kbar; 16-25 km depth; 21-19.5 Ma), migmatisation and crystallization of the Ghumbur Ranjung leucogranite (Walker et al., 1999; Dèzes et al., 1999). This phase includes all the syn-metamorphic ductile 

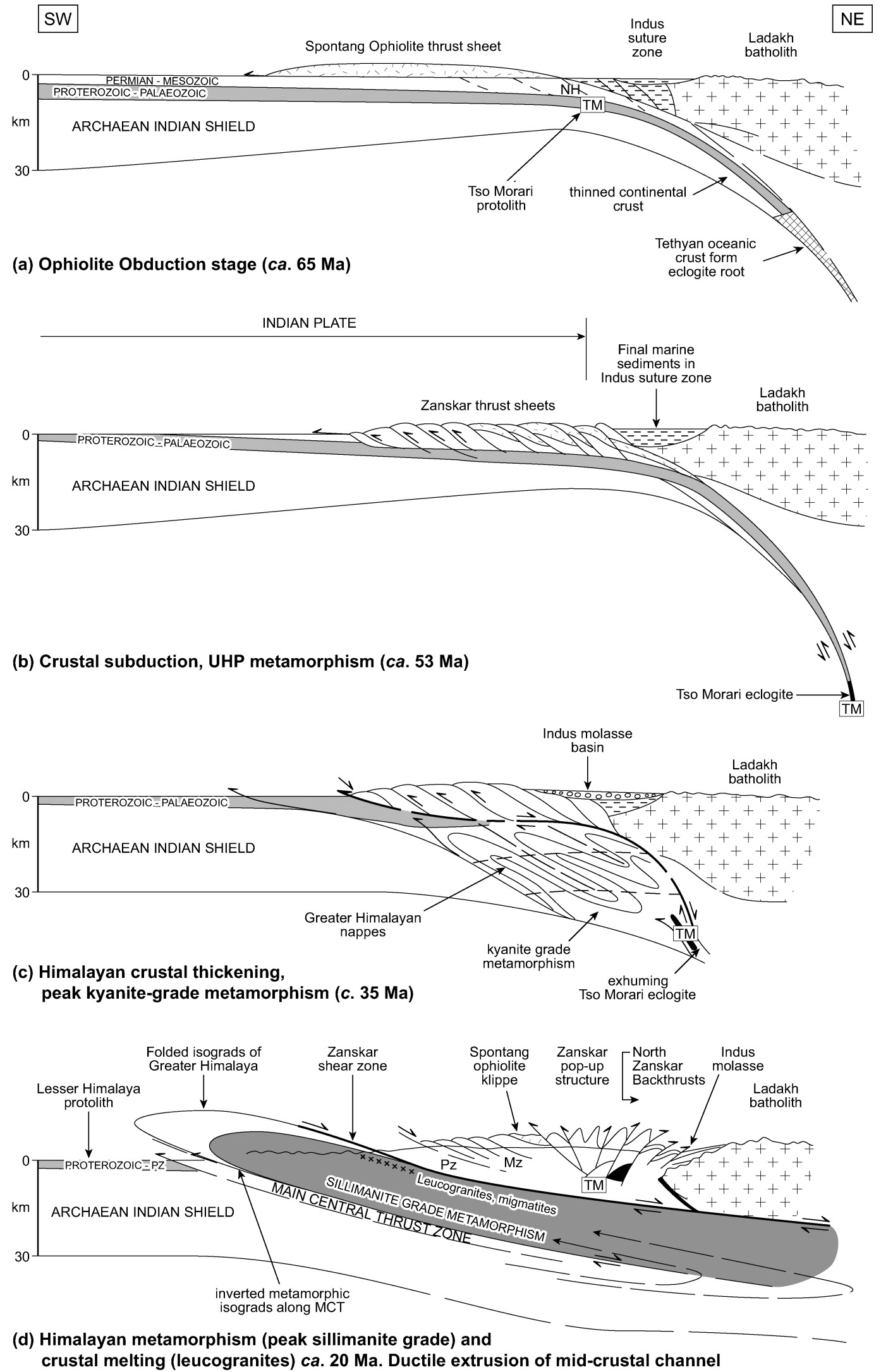

Figure 8 Model for the evolution of the western Himalaya, showing four stages of (a) ophiolite obduction, (b) deep crustal subduction of thinned leading edge of the Indian plate to coesite eclogite depths (ca 95-100 km), (c) the major crustal thickening event resulting in kyanite grade metamorphism, and (d) peak sillimanite grade metamorphism, widespread partial melting and generation of migmatites and leucogranites. This phase resulted in ductile extrusion of the mid-crust (channel flow) between the ZSZ above and MCT zone below between a brittle deforming upper crust (Tethyan zone) and a rigid underthrusting granulite facies Indian shield below. 
deformation within the GHS slab. Following peak kyanite grade metamorphism, temperatures remained high across the GHS, but pressures decreased from 10-12 kbar to 4-6 kbar (Searle et al., 1992, 1999). It seems likely that widespread partial melting within the GHS core triggered channel flow. Leucogranite melts formed by in situ melting of a Haimanta-type protolith, were channeled laterally along giant sill complexes, fed by interconnecting dykes. Ductile shearing occurred along the major bounding shear zones of the GHS (ductile MCT at base, ductile ZSZ at top) accompanied channel flow (Figure 8d). Metamorphic isograds are right way-up along the ZSZ footwall, with metamorphic grade increasing with depth into the cores of the domes.

D5-(18-?14 Ma). This phase was continuous with D4, but includes all the post-metamorphic deformation events, mainly within the brittle field, during the later stages of exhumation of the GHS. Metamorphic isograds were folded around the major SWfacing Zanskar fold with inverted isograds along the basal MCT zone and right way-up isograds along ZSZ at the top of the GHS slab (Searle and Rex, 1989; Stephenson et al., 2000, 2001). Postmetamorphic extensional shear zones including Chenab-Kilar shear zone, Miyar-Dharlang shear zone and Zanskar shear zone were active during this time. The MCT ductile shear zone evolved into a brittle thrust fault along the base of the inverted isograd sequence with time.

D6- $(<14 \mathrm{Ma})$. As the GHS was exhumed and cooled below the muscovite closure temperature $\left(350^{\circ} \mathrm{C}\right)$, deformation in the slab changed from ductile to brittle. Brittle MCT thrust faulting occurred along the base of the MCT ductile shear zone and brittle low-angle faulting (Zanskar normal fault) occurred along the top of the ductile ZSZ. Large-scale folding resulting in the Kishtwar Window, Kulu Window and Chamba syncline, folded all the ductile shear zones and brittle faults. Late-stage compression also resulted in NE-directed backthrusting of Kashmir Palaeozoic sedimentary rocks over already exhumed GHS kyanite grade rocks along the Warwan backthrust.

\section{Discussion: 'Extension' within a compressive orogen}

Low-angle normal faults are frequently thought of as a mechanical paradox in compressional mountain belts. The major problem is how can the kinematics of normal faulting and extension be reconciled with compression and crustal thickening? Do normal faults in compressional mountain belts represent alternating periods of extension and crustal thinning with periods of compression and crustal thickening, or are the normal faults synchronous with thrusting? Can the normal faults be related to 'orogenic collapse', thinning of the crust and lowering of surface elevation? How can upper crustal extension be balanced in the lower crust? How can normal faulting and extension exhume lower crustal metamorphic rocks?

The determination of timing of motion on thrusts and normal faults is clearly extremely important, although this is not easy to ascertain with precision. Simple balancing rules of mass conservation suggest that, if a package of rocks has moved a large distance carried above a thrust fault, then either the trailing edge of the thrust sheet is a synchronous normal fault, or there has been a large amount of crustal thinning and stretching (a 'stretching fault' in the sense of Means [1989]). Many structural culminations are bounded above by thrust faults that have been reactivated as normal faults, when the hanging-wall is carried passively above an actively moving footwall (e.g., Banks and Warburton, 1986). In the Himalaya, several important conclusions can be drawn from the structural, metamorphic and geochronological evidence:

1. Thrust faults within the MCT zone along the base of the GHS were active at the same time as the normal faults along the STD (ZSZ) along the top of the GHS. The MCT-related thrusts propagated downward with time to the south or SW, and the STD- related normal faults propagated upward with time to the north or NW (Searle et al., 2003; Searle and Godin, 2003). This implies that, as the southward extruding GHS channel was internally flattening and thinning, as a result of a component of pure shear during south-directed simple shear (Law et al., 2004; Jessup et al., 2006), the GHS channel was actually expanding, as faults propagated upward and downward with time (Figure 9).

2. 'Orogenic collapse' implies that firstly, crustal shortening produced thick crust and high mountains, and secondly, crustal extension caused collapse, normal faulting and lowering of surface elevation. The Himalaya have been under whole crustal compression since the initial India-Asia collision approximately 50 m.y. ago (as opposed to Basin and Range whole lithosphere extension). GPS studies show that the range is still under compression today, and the Himalaya are still rising, not collapsing. The STD-related normal faults operated within a whole lithosphere compressive stress regime during a narrow time interval corresponding to the timing of metamorphism, deformation, and extrusion during channel flow.

3. In the Himalaya, it is apparent that the STD-related low-angle normal faults and shear zones separate packages of rocks that have been affected by compression at different times and different depths. The STD (or Zanskar Shear Zone in the west) separates Tethyan shelf sediments that have been shortened by $>80 \mathrm{~km}$ (Corfield and Searle, 2000) during the Middle Eocene to Oligocene above, from the GHS metamorphic rocks that have been shortened and metamorphosed during the late Oligocene and Miocene, below. Folding and thrusting above the STD (=ZSZ) ended as deformation propagated south into the GHS, and the Tethyan zone was carried passively, piggy-back fashion, during active extrusion of the footwall. Thus the STD (=ZSZ) can be described as a passive roof fault, in the sense of Banks and Warburton (1986). The implication of this is that the footwall and hanging wall of the STD cannot be internally consistently balanced, and that some footwall rocks must have extended to the north, beneath the southern margin of the Lhasa block.

4. Crustal extension alone cannot exhume lower crustal metamorphic rocks unless they have been pushed up by some other mechanism, such as mantle upwelling (as in the Basin and Range province) or thrusting at depth (as in the Himalaya). In the Himalaya, the STD normal faults do not exhume the footwall metamorphic rocks. Instead the STD acted as a passive roof fault whilst the footwall metamorphic rocks were uplifted above a deeper, active thrust, in this case the MCT, during Miocene channel flow extrusion (Searle et al., 2003; Law et al., 2004). If the MCT was responsible for uplifting the mid-crust metamorphic rocks of the GHS, then the STD acted as a passive roof fault at the same time (i.e. during the period $c a$. 21-16 Ma).

\section{Discussion: Location of the MCT}

There is great confusion in Himalayan literature concerning the precise location of the MCT. Since Heim and Gansser's (1939) original definition, it has subsequently been mapped as following the kyanite isograd (e.g., Bordet, 1961; Colchen et al., 1986) or even higher upsection within the GHS. Some authors have attempted to define the location of the MCT on stratigraphic-lithogical differences (Colchen et al., 1986) or differences in Nd isotopic or detrital zircon ages (Robinson et al., 2001; Richards et al., 2005). Others have defined the location of the MCT using the distribution of young Pliocene Th$\mathrm{Pb}$ ages of monazites (e.g., Harrison et al., 1997; Kohn et al., 2001; Catlos et al., 2001, 2002). None of these criteria can be used for defining a thrust fault (Searle et al., 2007).

The true MCT location has to be mapped using strain criteria. Since the metamorphism occurred prior to shearing along the MCT, the condensed and inverted isograd sequence always coincides with the high strain zone. Around the Kishtwar Window, the MCT is a 


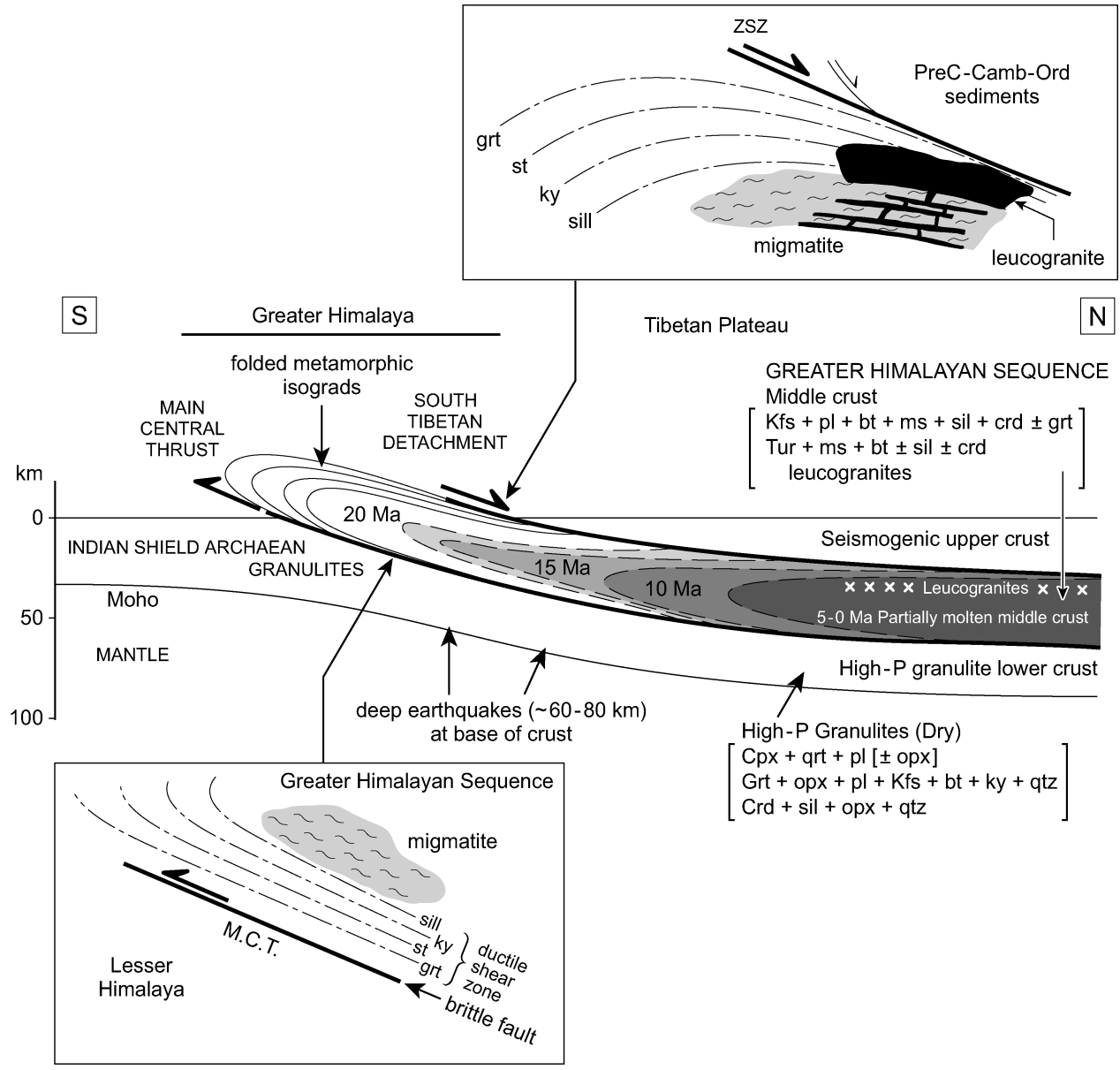

Figure 9 Channel Flow model of ductile extrusion of a partially molten mid-crustal slab (GHS) in the Himalaya during the Early Miocene, bounded above by a low-angle normal sense ductile shear zone and fault (ZSZ) and below by a $S W$-vergent ductile shear zone and thrust fault (MCT).

source (Richards et al., 2005; Martin et al., 2005).

Both eNd(500) values and detrital zircon ages in the GHS and the Tethyan zone overlap, confirming the lateral correlation between the two zones. Ahmad et al. (2000) also recognized that 'Outer Lesser Himalaya' rocks had identical Nd model ages to those of the GHS, supporting the contention that the 'Upper Lesser Himalayan crystallines' should be included in the GHS above the MCT. Martin et al. (2005) proposed that the $1.5 \mathrm{~km}$ ductile shear zone of the MCT was 'superimposed on the Greater Himalaya-Lesser Himalaya contact'. However, the MCT is a thrust that cuts up-stratigraphic section in the restored section, whereas the isotopic distinction is purely a stratigraphic boundary.

\section{Conclusions}

The metamorphism of the GHS and North Himalayan domes shows that the earliest effects were the deepest, and that pressures decreased as temperatures increased with time. Three stages can be recognized within an overall continuum: (1) UHP coesite eclogite metamorphism preserved within the North Himalayan Tso Morari nappe $\left(\sim 27 \mathrm{kbar} ; 550-600^{\circ} \mathrm{C}\right.$; $\sim 54-46 \mathrm{Ma}),(2)$ kyanite grade GHS metamorphism $\left(550-680^{\circ} \mathrm{C} ; 9.5-10.5\right.$ kbar; 37-30 Ma), and (3) sillimanite grade GHS metamorphism and

ductile shear zone up to $1.5-2 \mathrm{~km}$ thick that corresponds to the kyanite to garnet isograds with a brittle thrust fault along the base (Stephenson et al., 2000, 2001). Similar geometries of a ductile shear zone with a brittle thrust along the base (Figure 9) are also present in MCT sections elsewhere along the Himalaya (e.g., Searle et al., 2003, 2006, 2007; Searle and Szulz, 2005; Jessup et al., 2006). Restored sections demonstrate that the basal detachments of the Greater Himalaya (MCT) followed a flat within the Neoproterozoic Haimanta Group shales for a large distance. No Archean rocks occur in the exposed GHS, although it is possible that the deepest levels of the MCT could extend down into the Indian basement.

\section{Isotopic 'mapping' in the Himalaya}

Whole rock $\mathrm{Nd}$ isotope data give information on the stratigraphic age and provenance of the source area. U-Pb ages of detrital zircons give information on the age of melt source rocks. Both data sets provide key information on stratigraphy, not structure (i.e., Greater or Lesser Himalaya, above or below the MCT) as commonly mistakenly inferred (e.g., Ahmed et al., 2000; DeCelles et al., 2000; Robinson et al., 2001; Richards et al., 2005). Restoration of the Lesser Himalaya, Greater Himalaya and Tethyan Himalaya shows that stratigraphy can be correlated across all three zones (Figure 7). The isotopic distinctions are therefore not between Greater and Lesser Himalayan structural units, but are purely stratigraphic age distinctions. Thus, Lesser Himalayan rocks have eNd(500) values of -15 to -20 and detrital zircon ages $(2.6-1.85 \mathrm{Ga})$ characteristic of a Late Archean-Early Proterozoic source, whereas Greater Himalayan rocks have $\mathrm{eNd}(500)$ values of -2 to -14 and detrital zircon ages $(1.7-0.5 \mathrm{Ga})$ characteristic of a Late Proterozoic-Early Palaeozoic migmatisation $\left(650-770^{\circ} \mathrm{C}\right.$; 4.5-7 kbar; $\left.26-19.5 \mathrm{Ma}\right)$. The exhumation of each metamorphic package was brought about by thrust faulting below and normal faulting above, both in the Tso Morari dome and along the Greater Himalaya. It appears that, although high temperatures were attained by $37 \mathrm{Ma}$, melting did not occur along the upper structural levels of the GHS until 26-19.5 Ma in Zanskar (Noble and Searle, 1995, Walker et al., 1999, Dèzes et al., 1999; Robyr et al., 2006). These ages suggest that it must have been the melting episode that triggered channel flow and ductile extrusion. The timing of granite melting also coincides with the timing of increased cooling rates, erosion rates and exhumation of the GHS, and increased sedimentation rates in the Siwalik foreland basin.

The geometry of metamorphic isograds and the timing constraints of peak metamorphism, melting and motion along the ZSZ and MCT shear zones, suggest that during the period 26-18 Ma a mid-crustal layer or slab of high-temperature partially molten gneiss and migmatite was extruded southwest between crustal scale shear zones (MCT below, STD or ZSZ above). The map pattern of metamorphic isograds in the northwestern Himalaya shows that originally right way-up isograds have been affected by post-metamorphic folding and faulting. Inverted metamorphic isograds along the MCT zone can be mapped around a major SW-verging, NW-plunging fold axis to link with right way-up isograds in the footwall of the ZSZ at the top of the slab. In the far NW corner of Zanskar, the ZSZ and the MCT merge at a branch line, the only place in the entire Himalaya where this can be observed. This point is the axis of the huge SWvergent recumbent fold of the metamorphic isograds of the GHS (Searle and Rex, 1989). These observations support the model of southwestward extrusion of the GHS mid-crustal channel beneath the locked passive roof fault (ZSZ) above. Structural geometry and 
P-T conditions of footwall gneisses indicate about 60-100 km extrusion of footwall rocks towards the SW along the footwall of the ZSZ.

Along the upper contact of the GHS, there have been multiple episodes of low-angle normal faulting during crustal thickening, shortening and metamorphism in the footwall. The earliest normal faults beneath the Chamba klippe placed unmetamorphosed Proterozoic Haimanta Group sediments above metamorphic rocks of the GHS. The later ZSZ normal fault acted as a passive roof fault during Miocene crustal thickening in the footwall GHS rocks. Tethyan sediments above the ZSZ were folded and thrust earlier during the initial phase of crustal shortening. The ZSZ was active simultaneously with the Main Central Thrust along the base of the GHS. The MCT zone propagated structurally downwards with time, and normal faults along the top of the slab propagated structurally upwards with time. Both shear zones passed through the ductilebrittle transition at $\sim 16 \mathrm{Ma}$ as the GHS was extruded out to the southwest. There is no evidence of Pliocene reactivation of the MCT and no evidence that either the MCT or the ZSZ is active today in the western Himalaya. Following thrust-related exhumation and cooling of the GHS rocks above the MCT, thrusting propagated southwest into the Lesser Himalaya and Main Boundary Thrust sheet. The most recent thrust that is actively breaking out into the foreland south of the MBT involves motion along the 100 $\mathrm{km}$ long rupture associated with the Mw 7.8 8th October 2005 Kashmir earthquake (Avouac et al., 2006).

The Main Central Thrust is a brittle thrust fault along the base of a $1.5-3 \mathrm{~km}$ thick ductile shear zone that corresponds to the inverted metamorphic sequence. Although the MCT must have initiated during the regional kyanite and sillimanite grade metamorphism, the shear zone and thrust fault seen today are a snap shot of a long-lived shear zone that was continually evolving in time (Oligocene-Miocene) and space (from $35 \mathrm{~km}$ depth to surface). Restoration of the Zanskar-Lahoul Greater Himalayan structures shows that the protoliths of the GHS metamorphic rocks include Vendian-Cambrian shales (Haimanta Group), CambrianOrdovician granites and upper Palaeozoic to Triassic-Jurassic carbonates, equivalent to rocks of the adjacent Tethyan zone. Stratigraphy between Lesser Himalaya, Greater Himalaya and Tethyan Himalaya structural units can be matched across the restored MCT and ZSZ shear zones. There is no evidence of any suture zone or terrane boundary at the MCT as in the model of DeCelles et al. (2001) and Robinson et al. (2003). The structural and thermal evolution of the western Himalaya support the models of post-metamorphic folding of isograds on a very large scale (Searle and Rex, 1989; Walker et al., 1999; Stephenson et al., 2001) and channel flow of a ductile, high-temperature, partially molten layer of middle crust along the Greater Himalaya (Grujic et al., 1996, 2002; Beaumont et al., 2001, 2004; Searle et al., 2003, 2006; Searle and Szulc, 2005, Jessup et al., 2006; Law et al., 2006).

\section{Acknowledgements}

This work was carried out using NERC and Royal Society research grants. We are grateful to Rick Law, Dave Waters, Randy Parrish, and Steve Noble for numerous discussions about Himalayan geology, and to Fida Hussein (Leh), Sonam Targis (Marka), Ali Hussein Shillikchey (Kargil), Ghulam Murtaza (Padam) and Tsawang Dorjey (Jildo) for logistical assistance over many years in Zanskar.

\section{References cited}

Arita, K., 1983, Origin of the inverted metamorphism of the Lower Himalayas, central Nepal: Tectonophysics, v. 95, pp. 43-60.

Ahmad, T., Harris, N., Bickle, M., Chapman, H., Bunbury, J. and Prince, C., 2000, Isotopic constraints on the structural relationships between the Lesser Himalayan series and the high Himalayan crystalline series, Garhwal Himalaya. Geological Society of America Bulletin, v. 112, pp. 467-477.
Avouac, J-P., Ayoub, F., Leprince, S., Konca, O., and Helmberger, D.V., 2006 The 2005, MW 7.6 Kashmir earthquake: Sub-pixel correlation of ASTER images and seismic waveforms analysis. Earth and Planetary Science Letters.

Banks, C.J. and Warburton, J., 1986, 'Passive roof' duplex geometry in the frontal structures of the Kirthar and Sulaiman mountain belts, Pakistan. J. Structural Geology, v. 8, pp. 229-37.

Baud, A., Gaetani, M., Garzanti, E., Fois, E., Nicora, A. and Tintori, A., 1984 Geological observations in southeastern Zanskar and adjacent Lahoul area (northwestern Himalaya). Ecl. Geol. Helv. v. 77, pp. 171-197.

Beaumont, C., Jamieson, R.A., Nguyen, M.H. and Lee, B., 2001, Himalayan tectonics explained by extrusion of a low-viscosity crustal channel coupled to focused surface denudation. Nature, v. 414, pp. 738-742.

Beaumont, C., Jamieson, R.A., Nguyen, M.H. and Medvedev, S. 2004. Crustal channel flows: 1 . Numerical models with applications to the tectonics of the Himalayan-Tibetan orogen. Journal of Geophysical Research, v. 109: B06406 29p.

Bordet, P. 1961. Recherches Géologiques dans l'Himalaya du Népal, Région du Makalu. CNRS, Paris, 275p.

Burchfiel, B.C., Zhiliang, C., Hodges, K.V., Yuping, L., Royden, L., Changrong, D., and Jiene, X., 1992. The South Tibetan Detachment System, Himalayan Orogen: extension contemporaneous with and parallel to shortening in a collisional mountain belt. Geological Society of America Special Paper, v. 269: 41 p.

Catlos, E.J., Harrison, T.M., Kohn, M.J., Grove, M., Ryerson, F.J., Manning, C.E. and Upreti, B.N., 2001, Geochronologic and thermobarometric constraints on the evolution of the Main Central Thrust, central Nepal Himalaya. Journal of Geophysical Research, v. 106, pp. 16177-16204.

Catlos, E.J., Harrison, T.M., Manning, C.E., Grove, M., Rai, S.M., Hubbard, M. and Upreti, B.N., 2002, Records of the evolution of the Himalayan orogen from in situ $\mathrm{Th}-\mathrm{Pb}$ ion microprobe dating of monazite: Eastern Nepal and western Garhwal. Journal of Asian Earth Sciences, v. 20, pp. 459-80.

Catlos, E.J., Dubey, C.S., Harrison, T.M. and Edwards, M.A., 2004, Late Miocene movement within the Himalayan Main Central Thrust shear zone, Sikkim, northeast India. Journal of Metamorphic geology, v. 22, p. 207-226.

Cawood, P.A., Johnson, M.R.W and Nemchin, A.A., 2007, Early Palaeozoic orogenesis alog the Indian margin of Gondwana: Tectonic response to Gondwana assembly. Earth and Planetary Science Letters, v. 255, pp. $70-84$.

Colchen, M., Le Fort, P. and Pecher, A., 1986, Annapurna ñ Manaslu ñ Ganesh Himal, CNRS, Paris, 136p.

Corfield, R.I. and Searle, M.P., 2000, Crustal shortening estimates across the north Indian continental margin, Ladakh, NW India. In: Khan, M.A., Treloar, P.J., Searle, M.P. and Jan, M.Q. (eds) Tectonics of the Nanga Parbat syntaxis and the Western Himalaya. Geological Society, London, Special Publication, v. 170, pp. 395-410.

DeCelles P.G., Gehrels, G.E., Quade, J., Lareau, B. and Spurlin, M., 2000, Tectonic implications of $\mathrm{U}-\mathrm{Pb}$ zircon ages of the Himalayan orogenic belt in Nepal. Science, v. 288, pp. 497-9.

de Sigoyer, J., Chavangnac, V., Blichert-Toft. J., Villa, I.M., Luais, B., Guillot, S., Cosca, M. and Mascle, G., 2000, Dating the Indian continental subduction and collisional thickening in the northwest Himalaya: Multichronology of the Tso Morari eclogites. Geology, v. 28, pp. 487-490.

de Sigoyer, J., Guillot, S., and Dick, P., 2004, Exhumation of the ultrahigh-pressure Tso Morari unt in eastern Ladakh (NW Himalaya): a case study. Tectonics, v. 23: doi:10.1029/2002TC001492.

Dezes, P.J., Vannay, J-C., Steck, A., Bussy, F. and Cosca, M., 1999, Synorogenic extension: Quantitative constraints on the age and displacement of the Zanskar shear zone (northwest Himalaya). Geological Society of America Bulletin, v. 111, pp. 364-74.

Epard, J-L., Steck, A., Vannay, J-C., and Hunziker, J., 1995, Tertiary Himalayan structures and metamorphism in the Kulu valley (Mandi-Koksar transect of the western Himalaya)-Shikar Beh nappe and Crystalline nappe. Schweiz. Mineral. Petrogr. Mitt., v. 75, pp. 59-84.

Frank, W., Grasemann, B., Guntli, P., and Miller, C., 1995, Geological Map of the Kishtwar-Chamba-Kulu region (NW Himalaya, India). Jb. Geol. Bundesanstalt, Wien, v. 138/2, pp. 299-308.

Gaetani, M., and Garzanti, E., 1991, Multi-cyclic history of the northern India continental margin. (NW Himalaya). Bull. Am. Assoc. Pet. Geol. v. 75/9, pp.1427-46.

Garzanti, E., Baud, A., and Mascle, G., 1987, Sedimentary record of the northward flight of India and its collision with Eurasia (Ladakh Himalaya, India). Geodynamica Acta, v. 1, pp. 297-312.

Girard, M., and Bussy, F., 1999, Late Pan-African magmatism in the Himalaya: new geochronological data from the Ordovician Tso Morari metagranites (Ladakh, NW India). Schweiz. Mineral. Petrogr. Mitt., v. 79, pp. 399-418.

Grasemann, B., Fritz, H. and Vannay, J-C., 1999, Quantitative kinematic flow analysis from the Main Central Thrust zone (NW Himalaya): implications for a decelerating strain path and the extrusion of orogenic wedges. J. Structural Geology, v. 21, pp. 837-53. 
Grujic, D., Casey, M., Davidson, C., Hollister, L., Kundig, K., Pavlis, T. and Schmid, S., 1996, Ductile extrusion of the Higher Himalayan crystalline in Bhutan: evidence from quartz microfabrics. Tectonophysics, v. 260, pp. 21-43.

Grujic, D., Hollister, L. \& Parrish, R.R., 2002, Himalayan metamorphic sequence as an orogenic channel: insight from Bhutan. Earth and Planetary Science Letters, v. 198, pp. 177-191.

Harrison, T.M., Ryerson, F.J., LeFort, P., Yin, A., Lovera, O. and Catlos, E.J., 1997, A late Miocene-Pliocene origin for the central Himalayan inverted metamorphism. Earth and Planetary Science Letters, v. 146: E1-E8.

Heim, A. and Gansser, A., 1939, Central Himalaya, geological observations of the Swiss expedition 1936. Mem. Soc. Helv. Sci. Nat., v. 73, 245p.

Herren, E., 1987, Zanskar Shear Zone: Northeast-southwest extension within the Higher Himalayas (Ladakh, India). Geology, v. 15, pp. 409-413.

Hodges, K.V., Parrish, R.R., Housch, T.B., Lux, D.R., Burchfiel, B.C., Royden, L.H. \& Chen, Z., 1992, Simultaneous Miocene extension and shortening in the Himalayan orogen. Science, v. 258, pp. 1466-1470.

Hodges, K.V., Parrish, R.R. and Searle, M.P., 1996, Tectonic evolution of the central Annapurna Range, Nepalese Himalayas. Tectonics, v. 15, pp. 1264-1291.

Honegger, K, 1983. Strukturen und Metamorphose im Zanskar Kristallin (Ladakh-Kashmir, Indien). Unpublished PhD thesis, E.T.H. Zurich.

Jessup, M.J., Law, R.D., Searle, M.P., and Hubbard, M.S., 2006, Structural evolution and vorticity of flow during extrusion and exhumation of the Greater Himalayan Slab, Mount Everest massif, Tibet/Nepal: implications for orogen-scale flow partitioning. In: Law, R.D., Searle, M.P. \& Godin, L. (eds), Channel flow, extrusion, and exhumation in continental collision zones. Geological Society, London, Special Publication, v. 268, pp. 379-413.

Klemperer, S., 2006, In: Law, R.D., Searle, M.P. \& Godin, L. (eds), Channel flow, extrusion, and exhumation in continental collision zones. Geological Society, London, Special Publication, v. 268, pp. 39-70.

Kohn, M.J., Catlos, E.J., Ryerson, F.J. and Harrison, T.M., 2001, Pressure-temperature-time path discontinuity in the Main Central Thrust zone, central Nepal. Geology, v. 29, pp. 571-4

Kundig, R., 1989, Domal structures and high-grade metamorphism in the Higher Himalayan Crystalline, Zanskar region, northwest Himalaya, India. Journal of Metamorphic Geology, v. 7, pp. 43-55.

Law, R.D., Searle, M.P. and Simpson, R.L., 2004, Strain, deformation temperatures and vorticity of flow at the top of the Greater Himalayan Slab, Everest massif, Tibet. Journal of the Geological Society, London, v. 161, pp. 305-20.

Law, R.D., Searle, M.P., and Godin, L. (eds), Channel flow, extrusion, and exhumation in continental collision zones. Geological Society, London, Special Publication, v. 268

Leech, M.L., Singh, S., Jain, A.K., Klemperer, S.L., and Manickavasagam, R.M., 2005, The onset of India-Asia continental collision: Early, steep subduction required by the timing of UHP metamorphism in the Western Himalaya. Earth and Planetary Science Letters, v. 234, pp. 83-97.

Martin, A.J., DeCelles, P.G., Gehrels, G.E., Patchett, P.J., and Isachsen, C., 2005, Isotopic and structural constraints on the location of the Main Central Thrust in the Annapurna Range, central Nepal Himalaya. Geological Society of America Bulletin, v. 117, pp. 926-944.

Means, W.D., 1989, Stretching faults. Geology, v. 17, pp. 893-96.

Metcalfe, R.P., 1993, Pressure, temperature and time constraints on metamorphism across the Main Central Thrust zone and High Himalayan slab in the Garhwal Himalaya. In: Treloar, P.J. and Searle, M.P. (eds) Himalayan Tectonics, Geol. Soc. London spec. Pub. v. 74, pp. 485-509.

Miller, C., Thoni, M., Frank, W., Grasemann, B., Klotzli, U., Guntli, P., and Draganis, E., 2001, The early Palaeozoic magmatic event in the Northwest Himalaya, India: source, tectonic setting and age of emplacement. Geol. Mag. v. 138, pp. 237-251

Mohan, A., Windley, B.F., and Searle, M.P., 1989, Geothermobarometry and development of inverted metamorphism in the Darjeeling-Sikkim region of the eastern Himalaya. J. Met. Geol. v. 7, pp. 95-110.

Myrow, P.M., Hughes, N.C., Williams,I.S., Parcha, S.K., Thompson, K.R., Bowring, S.A. Peng, S.C., and Ahluwalia, A.D., 2003, Integrated tectonostratigraphic analysis of the Himalaya and implications for its tectonic reconstruction. Earth and Planetary Science Letters, v. 212, pp. 433-441.

Nelson, K.D. and 27 others, 1996, Partially molten middle crust beneath southern Tibet: synthesis of Project INDEPTH results. Science, v. 274, pp. 1684 88.

Noble, S.R. and Searle, M.P., 1995, Age of crustal melting and leucogranite formation from $\mathrm{U}-\mathrm{Pb}$ zircon and monazite dating in the western Himalaya, Zanskar, India. Geology, v. 12, pp. 1135-1138.

Noble, S.R., Searle, M.P. and Walker, C.B., 2001, Age and tectonic significance of Permian granites in Western Zanskar, High Himalaya. J. Geology, v. 109, pp. $127-135$

O'Brien, P., 2006, The age of deep, steep subduction in the NW Himalaya: relating zircon growth to metamorphic history. Comment. Earth and Planetary Science Letters, v.
O’Brien, P.J., Zotov, N., Law, R.D., Khan, M.A., and Jan, M.Q., 2001, Coesite in Himalayan eclogite and implications for models of India-Asia collision. Geology, v. 29, pp. 435-8.

Parrish, R.R., Gough, S.J., Searle, M.P., and Waters, D.J., 2006, Plate velocity exhumation of ultrahigh-pressure eclogites in the Pakistan Himalaya. Geology, v. 34, pp. 989-992.

Pognante, U., Casteli, D., Benna, P., Genovese, G., Oberli, F., Meier, M., and Tonarini, S., 1990, The crystalline units of the High Himalayas in the LahulZanskar region (NW India): metamorphic-tectonic history and geochronology of the collided and imbricated Indian plate. Geol. Mag., v. 127, pp. 101-116.

Richards, A., Argles. T., Harris, N., Parrish, R., Ahmad, T., Darbyshire, F., and Draganits, E., 2005, Himalayan architecture constrained by isotopic tracers from clastic sediments. Earth and Planetary Science Letters, v. 236, pp. 773-796.

Robinson, D., DeCelles, P.G., Patchett, P.J., and Garzione, C.N., 2001, The kinematic evolution of the Nepalese Himalaya interpreted from $\mathrm{Nd}$ isotopes. Earth and Planetary Science Letters, v. 192, pp. 507-521.

Robinson, D., DeCelles, P.G., Garzione, C.N., Pearson, O.N., Harrison, T.M., and Catlos, E.J., 2003, Kinematic model for the Main Central Thrust in Nepal. Geology, v. 31, pp. 359-62.

Robyr, M., Vannay, J-C., Epard, J.-L., and Steck, A., 2002, Thrusting, extension, and doming during the polyphase tectonometamorphic evolution of the high Himalayan crystalline zone in NW India. Journal of Asian Earth Sciences, v. 21, pp. 221-239.

Robyr, M., Hacker, B.R., and Mattinson, J.M., 2006, Doming in compressional orogenic settings: new geochronological constraints from the NW Himalaya, Tectonics, v. 25, doi:10.1029/2004TC001774.

Rowley, D.B., 1998, Minimum age of initiation of collision between India and Asia north of Mount Everest based on the subsidence history of the Zhepure Mountain section. J. Geology, v. 106: pp. 229-235.

Sachan, H.K., Mukerjee, B.K., Ogasawara, Y., Maruyama, S., Ishida, H., Muko, A., and Yosioka, N., 2004, Discovery of coesite from the Indus suture zone, Ladakh, India: evidence for deep subduction. Eur. J. Mineral., v. 16, pp 235-40.

Schlup, M., Carter, A., Cosca, M., and Steck, A., 2003, Exhumation history of eastern Ladakh revealed by ${ }^{40} \mathrm{Ar} /{ }^{39} \mathrm{Ar}$ and fission-track ages: the Indus River-Tso Morari transect, NW Himalaya. J. Geol. Soc. London, v. 160, pp. 385-399.

Searle, M.P., 1986, Structural evolution and sequence of thrusting in the High Himalayan, Tibetan-Tethys and Indus suture zones of Zanskar and Ladakh, Western Himalaya. Journal of the Structural Geology, v. 8, pp. 923-936.

Searle, M.P., 2001, Dating the Indian continental subduction and collisional thickening in the northwest Himalaya: Multichronology of the Tso Morari eclogites. Comment. Geology, v. pp.191-2.

Searle, M.P. and Fryer, B.J., 1986, Garnet, tourmaline and muscovite-bearing leucogranites, gneisses and migmatites of the Higher Himalayas from Zanskar, Kulu, Lahoul and Kashmir. In: Coward, M.P. and Ries, A.C. (eds), Collision Tectonics, Geological Society, London, Special Publication v. 19, pp. 83-94.

Searle, M.P. and Rex, A.J., 1989, Thermal model for the Zanskar Himalaya. Journal of Metamorphic Geology, v. 7, pp. 127-134.

Searle, M.P. and Godin, L., 2003, The South Tibetan Detachment and the Manaslu leucogranite: A structural reinterpretation and restoration of the Annapurna-Manaslu Himalaya, Nepal. J. Geology, v. 111, pp. 505-23.

Searle, M.P. and Szulc, A.G., 2005, Channel flow and ductile extrusion of the High Himalayan slab-the Kangchenjunga-Darjeeling profile, Sikkim Himalaya. J. Asian Earth Sciences, v. 25, pp. 173-185.

Searle, M.P., Cooper, D.J.W., and Rex, A.J., 1988, Collision tectonics of the Ladakh-Zanskar Himalaya. Philosophical Transactions of the Royal Society, London, v. A326, pp. 117-150.

Searle, M.P., Waters, D.J., Rex, D.C. and Wilson, R.N., 1992, Pressure, temperature and time constraints on Himalayan metamorphism from eastern Kashmir and western Zanskar. Journal of the Geological Society, London, v. 149 , pp. 753-773.

Searle, M.P., Corfield, R.I, Stephenson, B.J., and McCarron, J., 1997a, Structure of the north Indian continental margin in the Ladakh-Zanskar Himalayas: implications for the timing of obduction of the Spontang ophiolite, IndiaAsia collision and deformation events in the Himalaya. Geological Magazine, v. 134, pp. 297-316.

Searle, M.P., Parrish, R.R., Hodges, K.V., Hurford, A., Ayres, M.W., and Whitehouse, M.J., 1997b, Shisha Pangma leucogranite, South Tibetan Himalaya: Field relations, geochemistry, age, orgin and emplacement. Journal of Geology, v. 195, pp. 295-317.

Searle, M.P., Simpson, R.L., Law, R.D., Parrish, R.R., and Waters, D.J., 2003 , The structural geometry, metamorphic and magmatic evolution of the Everest massif, High Himalaya of Nepal-S. Tibet. J. Geol. Soc. London, v. 160, pp. 345-66.

Searle, M.P., Law, R.D., and Jessup, M.J., 2006, Crustal structure, restoration and evolution of the Greater Himalaya in Nepal-South Tibet: implications for channel flow and ductile extrusion of the middle crust. In: Law, R.D. 
Searle, M.P., and Godin, L. (eds), Channel flow, extrusion, and exhumation in continental collision zones. Geological Society, London, Special Publications, v. 268, pp. 355-378.

Searle, M.P., Waters, D.J., Dransfield, M.W., Stephenson, B.J., Walker, C.B., Walker, J.D., and Rex, D.C., 1999, Thermal and mechanical models for the structural and metamorphic evolution of the Zanskar High Himalaya. In: MacNiocaill, C. and Ryan, P.D. (eds), Continental Tectonics. Geological Society, London, Special Publication, v. 164, pp. 139-156.

Searle, M.P., Law, R.D., Godin, L., Larson, K.P., Streule, M.J., Cottle, J.M., and Jessup, M.J., 2007, Defining the Himalayan Main Central Thrust in Nepal. J. Geol. Soc. London, in press.

Spring, L. and Crespo, A., 1992, Nappe tectonics, extension and metamorphic evolution in the Indian Tethys Himalaya. Tectonics, v. 11, pp. 978-989.

Staubli, A., 1989, Polyphase metamorphism and the development of the Main Central Thrust. Journal of Metamorphic Geology, v. 7, pp. 73-93.

Steck, A., 2003, Geology of the NW Indian Himalaya. Eclogae Geologicae Helvetiae, v. 96, pp. 147-196.

Steck, A., Epard, J.L., Vannay, J-C., Hunzikar, J., Girard, M., Morard, A., and Robyr, M., 1998, Geological transect across the Tso Morari and Spiti areas: the nappe structures of the Tethys Himalaya. Eclogae Geologicae Helvetiae, v. 91 , pp. 103-121.

Steck, A., Epard, J.L., and Robyr, M., 1999, The NE-directed Shikar Beh nappe: A major structure of the High Himalaya. Eclogae Geologicae Helvetiae, v. 92, pp. 239-250.

Stephenson, B.J., Waters, D.J., and Searle, M.P., 2000, Inverted metamorphism and the Main Central Thrust: Field relations and thermobarometric constraints from the Kishtwar Window, NW Indian Himalaya. Journal of Metamorphic Geology, v. 18, pp. 571-590.

Stephenson, B.J., Searle, M.P., Waters, D.J., and Rex, D.J., 2001, Structure of the Main Central Thrust zone and extrusion of the High Himalayan deep crustal wedge, Kishtwar-Zanskar Himalaya. Journal of Geological Society, London, v. 158, pp. 637-652.

Stutz, E. and Thöni, M., 1987, The Lower Paleozoic Nyimaling granite in the Indian Himalaya (Ladakh): new $\mathrm{Rb} / \mathrm{Sr}$ data versus zircon typology. Geol. Rundsch., v. 76, pp. 307-317.

Thakur, V.C., 1992, Geology of Western Himalaya. Pergamon Press, Oxford, 366p.

Thakur, V.C., 1998, Structure of the Chamba nappe and position of the Main Central Thrust in Kashmir Himalaya. J. Asian Earth Sciences, v. 16, pp. 269-282.

Valdiya, K.S., 1980, Two intracrustal boundary thrusts of the Himalaya, Tectonophysics, v. 66, pp. 323-348.

Vance, D. and Harris, N., 1999, Timing of prograde metamorphism in the Zanskar Himalaya. Geology, v. 27, pp. 395-398.

Vannay, J-C., and Grasemann, B., 1998, Inverted metamorphism in the High Himalaya of Himachal Pradesh, NW India: phase equilibria versus thermobarometry. Schweiz. Mineral. Petrogr. Mitt. v. 78, pp. 109-35.

Vannay, J-C. and Grasemann, B., 2001, Himalayan inverted metamorphism and syn-convergence extension as a consequence of a general shear extrusion. Geol. Mag. v. 138, pp. 253-276.

Vannay, J-C. and Steck, A., 1995, Tectonic evolution of the High Himalaya in upper Lahoul (NW Himalaya, India). Tectonics, v. 14, pp. 253-63.

Vannay, J-C., Grasemann, B., Rahn, M., Frank, W., Carter, A., Baudraz, V., and Cosca, M., 2004, Miocene to Holocene exhumation of metamorphic crustal wedges in the NW Himalaya: Evidence for tectonic extrusion coupled to fluvial erosion. Tectonics, v. 23, doi: 10.1029/2002TC001429.

Walker, C.B., Searle, M.P., and Waters, D.J., 2001, An integrated tectonothermal model for the evolution of the High Himalaya in western Zanskar with constraints from thermobarometry and metamorphic modeling. Tectonics, $v$. 20, pp. 810-833.

Walker, J.D., Martin, M.W., Bowring, S.A., Searle, M.P., Waters, D.J., and Hodges, K.V., 1999, Metamorphism, melting and extension: age constraints from the High Himalayan slab of SE Zanskar and NW Lahoul. Journal of Geology, v. 107, pp. 473-495.

Wei, W., Unsworth, M., Jones, A., Booker, J., Tan, H., Nelson, D., Chen, L., Li, S., Solon, K., Bedrosian, P., Jin, S., Deng, M., Ledo, J., Kay, D., and Roberts, B., 2001, Detection of widespread fluids in the Tibetan crust by magnetotelluric studies. Science, v. 292, pp. 716-718.

Weismayr, G. and Grasemann, B., 2002, Eohimalayan fold and thrust belt: Implications for the geodynamic evolution of the NW Himalaya (India). Tectonics, v. 21: doi: 10,1029/2002TC001363.

Wyss, M., Hermann, J., and Steck, A., 1999, Structural and metamorphic evolution of the northern Himachal Himalaya, NW India (Spiti-eastern Lahul-Parvati valley traverse). Eclogae Geol. Helv., v. 92, pp. 3-44.
Yin, A., 2006, Cenozoic tectonic evolution of the Himalayan orogen as constrained by along-strike variation of structural geometry, exhumation history, and foreland sedimentation. Earth Science Reviews, v.76, pp.1-131.

Zhao, W., Nelson, K.D. and Team project INDEPTH, 1993, deep seismic reflection evidence for continental underthrusting beneath southern Tibet. Nature, v. 366, pp. 557-559.

Zhu, B., Kidd, W.S.F., Rowley, D.B., Currie, B.S., and Shafique, N., 2005, Age of initiation of the India-Asia collision in the East Central Himalaya. J. Geology, v. 113, pp. 265-285.

Michael Searle received his $P h D$ in 1980 and has worked for 25 years on the geology of the Himalaya in India, Nepal, Sikkim, Bhutan and Tibet, the Karakoram and Hindu Kush ranges of north Pakistan. His research interests include ophiolite obduction processes, crustal shorteningthickening processes, and the role of strike-slip faults in extrusion. He has also worked on the Oman Mountains, Syria, and more recently Burma, Thailand and Vietnam. He is a departmental lecturer in Earth Sciences at Oxford University and a Fellow of Worcester College, Oxford.

Ben Stephenson received his D.Phil from Oxford University in 1997 working on the Main Central thrust zone in the Kishtwar-Zanskar Himalaya, North India. He has worked for Shell International for 9 years, first in Holland studying fractured carbonates from around the world, then transferred to Shell Canada in 2004, where he is exploring for natural gas in the Rocky Mountains. Prior to Shell, he worked as a field geologist for the Cambridge Arctic Shelf Programme. Ben also has made three ski traverses of the Indian Himalaya in winter and founded the Zanskar Ski school in Padam.

James Walker received his D.Phil from Oxford University in 1998 working on the structural and metamorphic evolution of the Greater Himalayan series in Zanskar and Lahoul (North India). Since then he has worked as a geologist for Esso Petroleum Company UK, and is currently on assignment at Imperial Oil in Calgary, Canada.

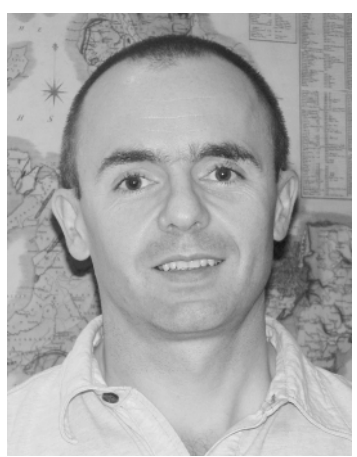

